\title{
Optimasi Operasi Unit-Unit Pembangkit Pada PLTU Barru
}

\author{
Remigius Tandioga ${ }^{*}$, Musrady Mulyadi ${ }^{2}$, Azwar $^{3}$ dan Widya Wirawati Rauf ${ }^{4}$ \\ 1,2,3,4 Jurusan Teknik Mesin, Politeknik Negeri Ujung Pandang, Makassar 90245, Indonesia \\ *remigius_tandioga@ymail.com
}

\begin{abstract}
The problem that is often faced by a power generating unit, especially thermal generators, is the high operating costs. In relation to operating costs, in this study, the calculation of operation optimization of thermal power plants aims to determine the optimal operating model, compare operating costs with various methods, and determine the lowest basic tariff cost for each generating unit. In this study, the method used for the optimal calculation of operating costs is the Lagrange multiplier method and dynamic programming. The main criteria that must be met is to know the input-output characteristics of the generating units. From the results of optimization calculations, it is known that the Lagrange multiplier method is more optimal than using the dynamic programming method even though the calculation results are almost the same. In general, the calculation results are more optimal than the real conditions of the PLTU Barru. Especially in May 2016, the optimal calculation results throughout the day (for 24 hours) with an average total power of $71.58 \mathrm{MW}(71.58 \%)$ namely on the 7th, 20th, 21st, 26th, 27th, 28th, 29th, 30, and 31. The real condition of the PLTU Barru is more optimal than the calculation results with an average total power of $50.36 \mathrm{MW}(50.36 \%)$ which is on the 4th at 17:00 - 24:00, the 5th at 01:00 - 16:00, the 6th at 01:00 - 17:00, the 8th at 17:00 - 24:00, the 10th at 01:00 08:00, the 11th at 01:00 - 12:00, date 18 hours 01:00 - 12:00, the 19th 01:00 - 02:00, the 22nd at 06:00, and the 25th at 21:00-22:00, and outside of that time the calculation results show the optimal value.
\end{abstract}

Keywords: Optimation; Optimal; Lagrange Multiplier Method; Dynamic Programming Method

\begin{abstract}
Abstrak: Masalah yang sering dihadapi oleh suatu unit pembangkit listrik khususnya pembangkit termal adalah adanya biaya operasi yang cukup tinggi. Sehubungan dengan biaya operasi maka dalam penelitian ini dilakukan perhitungan optimasi operasi pada pembangkit termal yang bertujuan mengetahui model operasi yang optimal, membandingkan biaya operasi dengan berbagai metode, dan menentukan biaya tarif dasar yang termurah di setiap unit-unit pembangkit. Dalam penelitian ini, metode yang digunakan untuk perhitungan optimal biaya operasi adalah metode Lagrange multiplier dan dynamic programming. Kriteria utama yang harus dipenuhi adalah mengetahui karakteristik input-output dari unit-unit pembangkit tersebut. Dari hasil perhitungan optimasi diketahui bahwa metode Lagrange multiplier lebih optimal dibandingkan dengan menggunakan metode dynamic programming meskipun hasil perhitungannya hampir sama. Pada umumnya hasil perhitungan lebih optimal dibandingkan kondisi nyata PLTU Barru. Khususnya pada bulan Mei 2016, hasil perhitungan yang optimal sepanjang hari (selama 24 jam) dengan daya total rata-rata 71,58 MW (71,58\%) yaitu pada tanggal 7, 20, 21, 26, 27, 28, 29, 30, dan 31. Adapun kondisi nyata PLTU Barru lebih optimal dibandingkan hasil perhitungan dengan daya total rata-rata 50,36 MW (50,36\%) yaitu pada tanggal 4 jam 17:00 - 24:00, tanggal 5 jam 01:00 - 16:00, tanggal 6 jam 01:00 - 17:00, tanggal 8 jam 17:00 - 24:00, tanggal 10 jam 01:00 - 08:00, tanggal 11 jam 01:00 12:00, tanggal 18 jam 01:00 - 12:00, tanggal 19 jam 01:00 - 02:00, tanggal 22 jam 06:00, dan tanggal 25 jam 21:00 - 22:00, dan diluar dari waktu tersebut hasil perhitungan menunjukkan nilai optimal
\end{abstract}

Kata kunci : Optimasi; Optimal; Metode Lagrange Multiplier; Metode Dynamic Programming

\section{PENDAHULUAN}

Pembangkit Untuk mencukupi kebutuhan beban, maka suatu sistem tenaga listrik diinterkoneksikan karena energi listrik tidak dapat disimpan maka energi listrik harus dibangkitkan pada saat dibutuhkan. Energi listrik yang disalurkan sebaiknya ekonomis, terutama dalam proses pembangkitan tenaga listrik pada pembangkit termal. Kendala terbesar yang sering dihadapi oleh suatu unit pembangkit listrik, khususnya yang menggunakan bahan bakar sebagai tenaga penggeraknya. Setiap tahun bahan bakar akan semakin menipis dan membutuhkan biaya operasi yang cukup besar. Maka untuk mengatasi hal tersebut perlu dilakukan suatu optimasi agar mendapatkan biaya operasi yang minimum dengan daya paling optimal disetiap unit pembangkit listrik.

Sebuah industri pembangkit listrik memiliki dan mengoperasikan lebih dari satu unit 
pembangkit. Demikian juga pada PLTU Barru dengan kapasitas sebesar 2 x 50 MW [1] memerlukan suatu metode untuk mengoptimalkan operasi pada unit-unit pembangkitnya. Adapun metode yang digunakan dalam pengoptimalisasian adalah metode Lagrange multiplier dan dynamic programming. Sehingga penulis mengadakan suatu penelitian mengenai "Optimasi Operasi Unit-Unit Pembangkit pada PLTU Barru".

\section{A. PLTU}

Pembangkit Listrik Tenaga Uap (PLTU) adalah pembangkit yang mengandalkan energi kinetik dari uap untuk menghasilkan energi listrik.

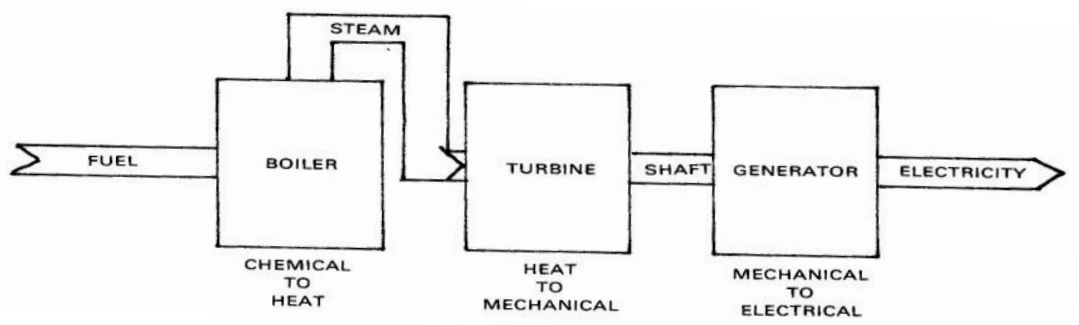

Gambar 1. Proses Konversi Energi pada PLTU

Salah satu PLTU di Sulawesi Selatan ialah PLTU Barru yang menghasilkan energi listrik sebesar 2 x 50 MW dengan menggunakan batubara sebagai bahan bakarnya [1].

\section{B. Optimasi Unit Pembangkit Termal}

Optimasi merupakan suatu proses untuk mencari kondisi yang optimum, dalam arti paling menguntungkan [2].

Penjadwalan operasi dan pembagian beban unit-unit pembangkit yang berbeda dapat memberikan biaya yang berbeda pula, tergantung dari karakteristik masing-masing unit pembangkit yang dioperasikan [3]. Dalam pengoperasian sistem yang optimal perlu mengacu pada suatu manajemen operasi yang baik terutama karena melibatkan biaya operasi yang besar, khususnya untuk pembangkit termal. Sehingga untuk mencapai pengoperasian yang optimal dan ekonomis perlu adanya optimasi penjadwalan operasi dan pembagian beban [3-7].

\section{Biaya Operasi Pembangkit Termal}

\section{1). Karakteristik Input-Output}

Untuk unit pembangkit termal, karakteristik input-output disebut pemakaian bahan bakar sebagai fungsi dari daya yang dibangkitkan atau fungsi biaya operasi [8].

Input pada pembangkit termal berupa panas dari bahan bakar yang diberikan oleh boiler untuk menghasilkan output pembangkit (energi listrik), dapat ditulis dengan notasi $\mathrm{H}$ dengan satuan Ton/jam. Dapat pula dinyatakan dalam nilai uang yang menyatakan besarnya biaya yang di perlukan, ditulis dengan notasi $\mathrm{C}$ dengan satuan $\mathrm{Rp} / \mathrm{h}$ sedangkan output pembangkit adalah daya listrik yang dikeluarkan oleh generator untuk mensuplai beban ditulis dengan notasi P dengan satuan MW.

Pada umumnya karakteristik input-output pembangkit termal didekati dengan fungsi polinomial orde dua yaitu:

$$
\mathrm{H}_{\mathrm{n}}=\alpha_{\mathrm{n}}+\beta_{\mathrm{n}} \mathrm{P}_{\mathrm{n}}+\gamma_{\mathrm{n}} \mathrm{P}_{\mathrm{n}}^{2}
$$

dimana :

$\mathrm{H}_{\mathrm{n}} \quad=$ Input bahan bakar pembangkit termal unit ke-n (Ton/jam).

$\mathrm{P}_{\mathrm{n}} \quad=$ Output pembangkit termal unit ke-n (MW). 
64 Remigius Tandioga, Musrady Mulyadi, Azwar, Widya Wirawati Rauf. Optimasi Operasi Unit-Unit Pembangkit Pada PLTU Barru

$\alpha_{\mathrm{n}}, \beta_{\mathrm{n}}, \gamma_{\mathrm{n}}=$ Konstanta input-output pembangkit termal unit ke-n.

Penentuan parameter $\alpha_{\mathrm{n}}, \beta_{\mathrm{n}}, \gamma_{\mathrm{n}}$ membutuhkan data yang berhubungan dengan input bahan bakar $\mathrm{H}_{\mathrm{n}}$ dan output pembangkit $\mathrm{P}_{\mathrm{n}}$. Kemudian data tersebut diolah dengan menggunakan metode regresi kuadrat.

Metode regresi kuadrat digunakan untuk mecari suatu fungsi tertentu yang dihasilkan dari data pengamatan. Cara penyelesaian dengan menggunakan metode regresi kuadrat sebagai berikut:

$$
\mathrm{S}=\Sigma\left(\alpha_{\mathrm{n}}+\beta_{\mathrm{n}} \mathrm{P}_{\mathrm{n}}+\gamma_{\mathrm{n}} \mathrm{P}_{\mathrm{n}}^{2}-\mathrm{H}_{\mathrm{n}}\right)^{2}
$$

Dimana persyaratan yang harus dipenuhi sebagai berikut:

$$
\begin{aligned}
& \frac{\partial S}{\partial \alpha}=\Sigma 2\left(\alpha_{\mathrm{n}}+\beta_{\mathrm{n}} \mathrm{P}_{\mathrm{n}}+\gamma_{\mathrm{n}} \mathrm{P}_{\mathrm{n}}^{2}-\mathrm{H}_{\mathrm{n}}\right)=0 \ldots \ldots \\
& \frac{\partial S}{\partial \beta}=\Sigma 2 \mathrm{P}_{\mathrm{n}}\left(\alpha_{\mathrm{n}}+\beta_{\mathrm{n}} \mathrm{P}_{\mathrm{n}}+\gamma_{\mathrm{n}} \mathrm{P}_{\mathrm{n}}^{2}-\mathrm{H}_{\mathrm{n}}\right)=0 . . \\
& \frac{\partial S}{\partial \gamma}=\Sigma 2 \mathrm{P}_{\mathrm{n}}^{2}\left(\alpha_{\mathrm{n}}+\beta_{\mathrm{n}} \mathrm{P}_{\mathrm{n}}+\gamma_{\mathrm{n}} \mathrm{P}_{\mathrm{n}}{ }^{2}-\mathrm{H}_{\mathrm{n}}\right)=0
\end{aligned}
$$

Sehingga :

$$
\begin{aligned}
& (\mathrm{N}) \alpha_{\mathrm{n}}+\left(\Sigma \mathrm{P}_{\mathrm{n}}\right) \beta_{\mathrm{n}}+\left(\Sigma \mathrm{P}_{\mathrm{n}}^{2}\right) \gamma_{\mathrm{n}}=\Sigma \mathrm{H}_{\mathrm{n}} \ldots \ldots \ldots . . . \\
& \left(\Sigma \mathrm{P}_{\mathrm{n}}\right) \alpha_{\mathrm{n}}+\left(\Sigma \mathrm{P}_{\mathrm{n}}^{2}\right) \beta_{\mathrm{n}}+\left(\Sigma \mathrm{P}_{\mathrm{n}}^{3}\right) \gamma_{\mathrm{n}}=\Sigma \mathrm{H}_{\mathrm{n}} \mathrm{P}_{\mathrm{n}} \ldots \\
& \left(\Sigma \mathrm{P}_{\mathrm{n}}^{2}\right) \alpha_{\mathrm{n}}+\left(\Sigma \mathrm{P}_{\mathrm{n}}^{3}\right) \beta_{\mathrm{n}}+\left(\Sigma \mathrm{P}_{\mathrm{n}}^{4}\right) \gamma_{\mathrm{n}}=\Sigma \mathrm{H}_{\mathrm{n}} \mathrm{P}_{\mathrm{n}}^{2}
\end{aligned}
$$

Maka akan membentuk suatu Sistem Persamaan Linier Tiga Variabel (SPLTV) dengan orde 3 pada persamaan (6), (7), dan (8), bila disusun sebagai berikut :

$$
\left[\begin{array}{cll}
\mathrm{N} & \Sigma \mathrm{P}_{\mathrm{n}} & \Sigma \mathrm{P}_{\mathrm{n}}{ }^{2} \\
\Sigma \mathrm{P}_{\mathrm{n}} & \Sigma \mathrm{P}_{\mathrm{n}}{ }^{2} & \Sigma \mathrm{P}_{\mathrm{n}}{ }^{3} \\
\Sigma \mathrm{P}_{\mathrm{n}}{ }^{2} & \Sigma \mathrm{P}_{\mathrm{n}}{ }^{3} & \Sigma \mathrm{P}_{\mathrm{n}}{ }^{4}
\end{array}\right]\left[\begin{array}{c}
\alpha_{n} \\
\beta_{n} \\
\gamma_{n}
\end{array}\right]=\left[\begin{array}{c}
\Sigma \mathrm{H}_{\mathrm{n}} \\
\Sigma \mathrm{H}_{\mathrm{n}} \mathrm{P}_{\mathrm{n}} \\
\Sigma \mathrm{H}_{\mathrm{n}} \mathrm{P}_{\mathrm{n}}{ }^{2}
\end{array}\right]
$$

Solusi SPAL pada persamaan (9) dapat dilakukan dengan cara:

2). Analitis (aljabar) yaitu dengan menggunakan aturan Cramer

$$
\begin{aligned}
& \alpha_{n}=\frac{\left|\begin{array}{ccc}
\Sigma \mathrm{H}_{\mathrm{n}} & \Sigma \mathrm{P}_{\mathrm{n}} & \Sigma \mathrm{P}_{\mathrm{n}}{ }^{2} \\
\Sigma \mathrm{H}_{\mathrm{n}} \mathrm{P}_{\mathrm{n}} & \Sigma \mathrm{P}_{\mathrm{n}}{ }^{2} & \Sigma \mathrm{P}_{\mathrm{n}}{ }^{3} \\
\Sigma \mathrm{H}_{\mathrm{n}} \mathrm{P}_{\mathrm{n}}{ }^{2} & \Sigma \mathrm{P}_{\mathrm{n}}{ }^{3} & \Sigma \mathrm{P}_{\mathrm{n}}{ }^{4}
\end{array}\right|}{\left|\begin{array}{ccc}
\mathrm{N} & \Sigma \mathrm{P}_{\mathrm{n}} & \Sigma \mathrm{P}_{\mathrm{n}}{ }^{2} \\
\Sigma \mathrm{P}_{\mathrm{n}} & \Sigma \mathrm{P}_{\mathrm{n}}{ }^{2} & \Sigma \mathrm{P}_{\mathrm{n}}{ }^{3} \\
\Sigma \mathrm{P}_{\mathrm{n}}{ }^{2} & \Sigma \mathrm{P}_{\mathrm{n}}{ }^{3} & \Sigma \mathrm{P}_{\mathrm{n}}{ }^{4}
\end{array}\right|} . \\
& \beta_{n}=\frac{\left|\begin{array}{ccc}
\mathrm{N} & \Sigma \mathrm{H}_{\mathrm{n}} & \Sigma \mathrm{P}_{\mathrm{n}}{ }^{2} \\
\Sigma \mathrm{P}_{\mathrm{n}} & \Sigma \mathrm{H}_{\mathrm{n}} \mathrm{P}_{\mathrm{n}} & \Sigma \mathrm{P}_{\mathrm{n}}{ }^{3} \\
\Sigma \mathrm{P}_{\mathrm{n}}{ }^{2} & \Sigma \mathrm{H}_{\mathrm{n}} \mathrm{P}_{\mathrm{n}}{ }^{2} & \Sigma \mathrm{P}_{\mathrm{n}}{ }^{4}
\end{array}\right|}{\left|\begin{array}{ccc}
\mathrm{N} & \Sigma \mathrm{P}_{\mathrm{n}} & \Sigma \mathrm{P}_{\mathrm{n}}{ }^{2} \\
\Sigma \mathrm{P}_{\mathrm{n}} & \Sigma \mathrm{P}_{\mathrm{n}}{ }^{2} & \Sigma \mathrm{P}_{\mathrm{n}}{ }^{3} \\
\Sigma \mathrm{P}_{\mathrm{n}}{ }^{2} & \Sigma \mathrm{P}_{\mathrm{n}}{ }^{3} & \Sigma \mathrm{P}_{\mathrm{n}}{ }^{4}
\end{array}\right|} .
\end{aligned}
$$




$$
\gamma_{n}=\frac{\left|\begin{array}{ccc}
\mathrm{N} & \Sigma \mathrm{P}_{\mathrm{n}} & \Sigma \mathrm{H}_{\mathrm{n}} \\
\Sigma \mathrm{P}_{\mathrm{n}} & \Sigma \mathrm{P}_{\mathrm{n}}{ }^{2} & \Sigma \mathrm{H}_{\mathrm{n}} \mathrm{P}_{\mathrm{n}} \\
\Sigma \mathrm{P}_{\mathrm{n}}{ }^{2} & \Sigma \mathrm{P}_{\mathrm{n}}{ }^{3} & \Sigma \mathrm{H}_{\mathrm{n}} \mathrm{P}_{\mathrm{n}}{ }^{2}
\end{array}\right|}{\left|\begin{array}{ccc}
\mathrm{N} & \Sigma \mathrm{P}_{\mathrm{n}} & \Sigma \mathrm{P}_{\mathrm{n}}{ }^{2} \\
\Sigma \mathrm{P}_{\mathrm{n}} & \Sigma \mathrm{P}_{\mathrm{n}}{ }^{2} & \Sigma \mathrm{P}_{\mathrm{n}}{ }^{3} \\
\Sigma \mathrm{P}_{\mathrm{n}}{ }^{2} & \Sigma \mathrm{P}_{\mathrm{n}}{ }^{3} & \Sigma \mathrm{P}_{\mathrm{n}}{ }^{4}
\end{array}\right|}
$$

Sehingga diperoleh persamaan biaya bahan bakar sebagai berikut

$C_{n}=\alpha_{n}+\beta_{n} P_{n}+\gamma_{n} P_{n}^{2}(R p / h)$.

dimana :

$\mathrm{C}_{\mathrm{n}} \quad=$ Biaya bahan bakar pembangkit termal unit ke-n $(\mathrm{Rp} / \mathrm{h})$.

$\mathrm{P}_{\mathrm{n}} \quad=$ Output pembangkit termal unit ke-n (MW).

$\alpha_{\mathrm{n}}, \beta_{\mathrm{n}}, \gamma_{\mathrm{n}}=$ Konstanta input-output pembangkit termal unit ke-n.

Penentuan parameter $\alpha_{\mathrm{n}}, \beta_{\mathrm{n}}, \gamma_{\mathrm{n}}$ membutuhkan data yang berhubungan dengan input bahan bakar $\mathrm{H}_{\mathrm{n}}$ dan output pembangkit $\mathrm{P}_{\mathrm{n}}$

Untuk menggambarkan karakteristik input-output suatu unit pembangkit termal yang ideal dapat dilihat pada Gambar 2.

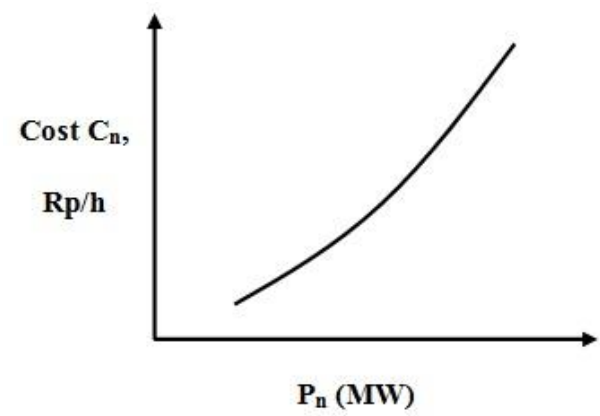

Gambar 2. Karakteristik Input-Output Unit Pembangkit Termal (Ideal), Kurva Biaya Bahan Bakar.

\section{Metode Lagrange Multiplier}

Metode Lagrange multiplier adalah sebuah metode untuk menentukan biaya/nilai maksimum atau minimum relatif dari suatu fungsi yang dibatasi oleh suatu kondisi [9].

Dalam menggunakan metode Lagrange multiplier harus dicari objective function yaitu biaya bahan bakar yang akan dicari minimumnya [10].

Pada umumnya pengoperasian pembangkit mempunyai batasan daya yang dibangkitkan. Generator dari setiap unit pembangkit seharusnya membangkitkan daya tidak melebihi nilai maksimum serta tidak boleh melebihi nilai minimumnya. Untuk itu diperlukan suatu optimasi pengoperasian pembangkit agar biaya pengoperasian tetap ekonomis. Syarat untuk beroperasi secara ekonomis [11]:

$$
\mathrm{P}_{\mathrm{n}(\min )} \leq \mathrm{P}_{\mathrm{n}} \leq \mathrm{P}_{\mathrm{n}(\max )} \quad \mathrm{n}=1, \ldots, \mathrm{n} .
$$


66 Remigius Tandioga, Musrady Mulyadi, Azwar, Widya Wirawati Rauf. Optimasi Operasi Unit-Unit Pembangkit Pada PLTU Barru

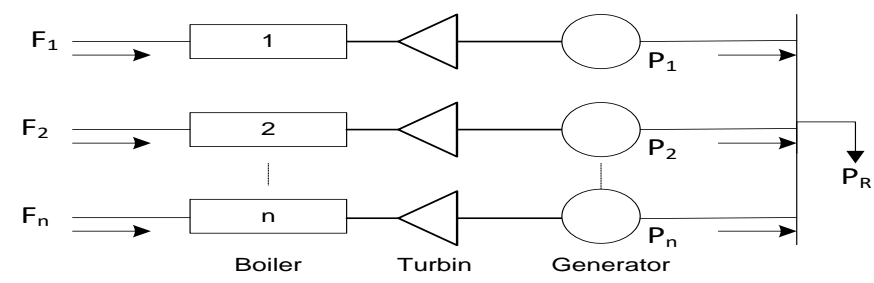

Gambar 3. Representasi Biaya Pembangkit, Daya Output dan Beban suatu Pusat Pembangkit Termal.

Biaya bahan bakar dan biaya pembangkit tenaga listrik dari suatu sistem tenaga listrik dengan mengabaikan rugi-rugi transmisi dapat dinyatakan sebagai berikut:

$$
\begin{aligned}
& \mathrm{C}_{\mathrm{t}}=\mathrm{C}_{1}+\mathrm{C}_{2}+\ldots .+\mathrm{C}_{\mathrm{n}}(\mathrm{Rp} / \mathrm{h}) \\
& \mathrm{P}_{\mathrm{R}}=\mathrm{P}_{\mathrm{t}}=\mathrm{P}_{1}+\mathrm{P}_{2}+\ldots .+\mathrm{P}_{\mathrm{n}}(\mathrm{MW}) \\
& \frac{\mathrm{dC}_{1}}{\mathrm{dP}_{1}}=\frac{\mathrm{dC}_{2}}{\mathrm{dP}_{2}}=\cdots=\frac{\mathrm{dC}_{n}}{\mathrm{dP}_{n}}=\lambda
\end{aligned}
$$

dimana :

$\lambda=$ Suatu nilai tertentu yang merupakan Lagrange multiplier (Pengalih multiplier) [11].

\section{E. Metode Dynamic Programming}

Dynamic programming merupakan suatu metoda untuk mencari alternatif yang optimum diantara beberapa alternatif yang bisa ditempuh, berupa kombinasi unit pembangkit termis yang terbaik untuk melayani beban tertentu agar didapat biaya bahan bakar yang minimal [10].

Dalam metode ini, peminimalan biaya dilakukan secara bertahap dimana dilakukan terhadap biaya minimum unit 1 yang sudah ditambah dengan biaya unit ke-2. Dari perhitungan tersebut didapatkan biaya minimum dari dua unit pembangkit serta keluaran unit 2. Kemudian dilakukan peminimalan untuk tiga unit. Demikian seterusnya hingga didapatkan biaya minimum untuk $\mathrm{n}$ unit pembangkit $(\mathrm{n}=$ jumlah unit pembangkit $)$ yang terdapat dalam pembangkit serta keluaran masingmasing unit tersebut [12].

Secara matematis optimasi biaya bahan bakar dengan metode dynamic programming dinyatakan sebagai berikut [13]:

$$
\mathrm{B}_{\mathrm{N}}(\mathrm{X})=\operatorname{Min}\left\{\mathrm{b}_{\mathrm{N}}(\mathrm{Y})+\mathrm{B}_{\mathrm{N}-1}(\mathrm{X}-\mathrm{Y})\right\}
$$

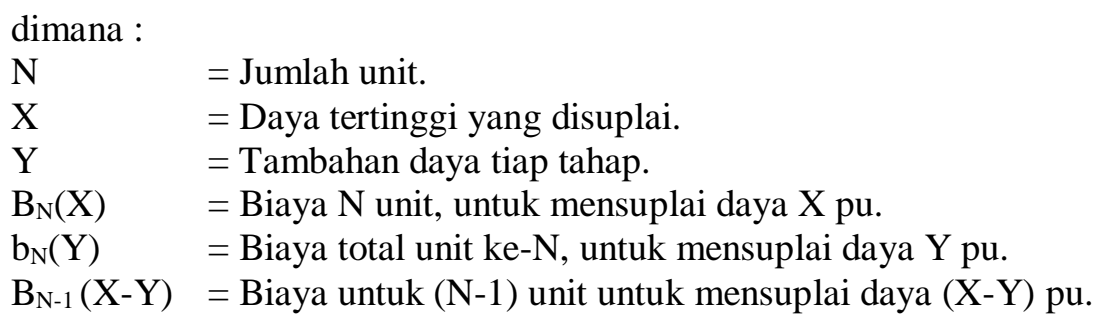

\section{METODE PENELITIAN}

Penelitian ini dilaksanakan pada bulan April 2016 sampai dengan bulan Oktober yang bertempat di PLTU Barru, Sulawesi Selatan.

Dalam melakukan penelitian ini, berikut alat dan bahan penelitian yang digunakan :

1). Literatur yaitu buku, jurnal, dan artikel ilmiah yang berhubungan dengan teknik operasi ekonomis unit-unit pada suatu pembangkit. 
2). Adapun dari sisi hardware dan software:

a). Prosessor Intel(R) core i5-4210U 64-bit

b). Microsoft office excel 2007

c). Matlab R2010b

d). Internet Browser : Google Chrome

\section{A. Teknik Pengumpulan Data}

Metode pengumpulan data ialah cara yang ditempuh untuk mengambil data dari variable penelitian tersebut. Metode yang digunakan dalam penelitian ini adalah wawancara, observasi secara langsung, pengumpulan data (dokumentasi), studi literatur. Metode diatas akan dijelaskan secara rinci sebagai berikut:

1). Wawancara yang dilakukan dengan mewawancarai narasumber yang berkompeten dengan bidang terkait terhadap topik dari proposal tugas akhir yang diangkat. Teknik wawancara yang penulis lakukan adalah menanyakan segala sesuatu yang tudak diketahui atau tidak jelas.

2). Observasi secara langsung adalah penulis ke lokasi penelitian untuk melakukan pengambilan data langsung terhadap objek penelitian.

3). Metode pengumpulan data (dokumentasi) adalah metode yang dilakukan untuk mengumpulkan seluruh data yang terkait dengan hal penelitian. Seluruh data tersebut diperoleh dari softcopy database perusahaan pengelolah pembangkit yakni PLTU Barru.

4). Studi literatur adalah penulis mengumpulkan data-data dengan membaca dan mempelajari berbagai literature-literatur yang ada sesuai dengan masalah yang diteliti.

\section{A. Teknik Analisa Data}

Dalam pengambilan data dilakukan langkah-langkah sebagai berikut:

1). Menentukan waktu dan lokasi penelitian.

2). Melakukan pengambilan data parameter yang dibutuhkan di PLTU Barru.

3). Mengambil data yang dibutuhkan.

4). Mengelolah data yang yang diperoleh.

5). Menghitung persamaan input-output.

6). Menghitung persamaan biaya bahan bakar.

7). Menghitung optimasi operasi unit-unit pembangkit untuk mendapatkan model operasi unit-unit pembangkit dengan menggunakan metode Lagrange multiplier dan metode dynamic programming.

8). Membandingkan model optimasi operasi unit-unit pembangkit yang diperoleh antara PLTU Barru, metode Lagrange multiplier dan metode dynamic programming untuk mendapatkan $\mathrm{m}$

9). Model yang paling ekonomis diantara ketiganya.

\section{B. Definisi Operasional}

Definisi operasional dimaksudkan untuk menghindari kesalahan pemahaman dan perbedaan penafsiran yang berkaitan dengan judul penelitian yaitu "Optimasi Operasi Unit-Unit Pembangkit pada PLTU Barru, maka definisi yang perlu dijelaskan yaitu:

1). Optimasi

Optimasi adalah suatu proses meninggikan atau meningkatkan. Dalam penelitian ini diartikan proses meninggikan atau meningkatkan ialah dengan biaya operasi yang minimum tetapi daya (MW) paling optimal pada suatu pembangkit listrik.

2). Operasi

Operasi dalam penelitian ini adalah proses suatu pembangkit mulai dari pemakaian bahan bakar hingga daya yang dibangkitkan (MW). 
68 Remigius Tandioga, Musrady Mulyadi, Azwar, Widya Wirawati Rauf. Optimasi Operasi Unit-Unit Pembangkit Pada PLTU Barru

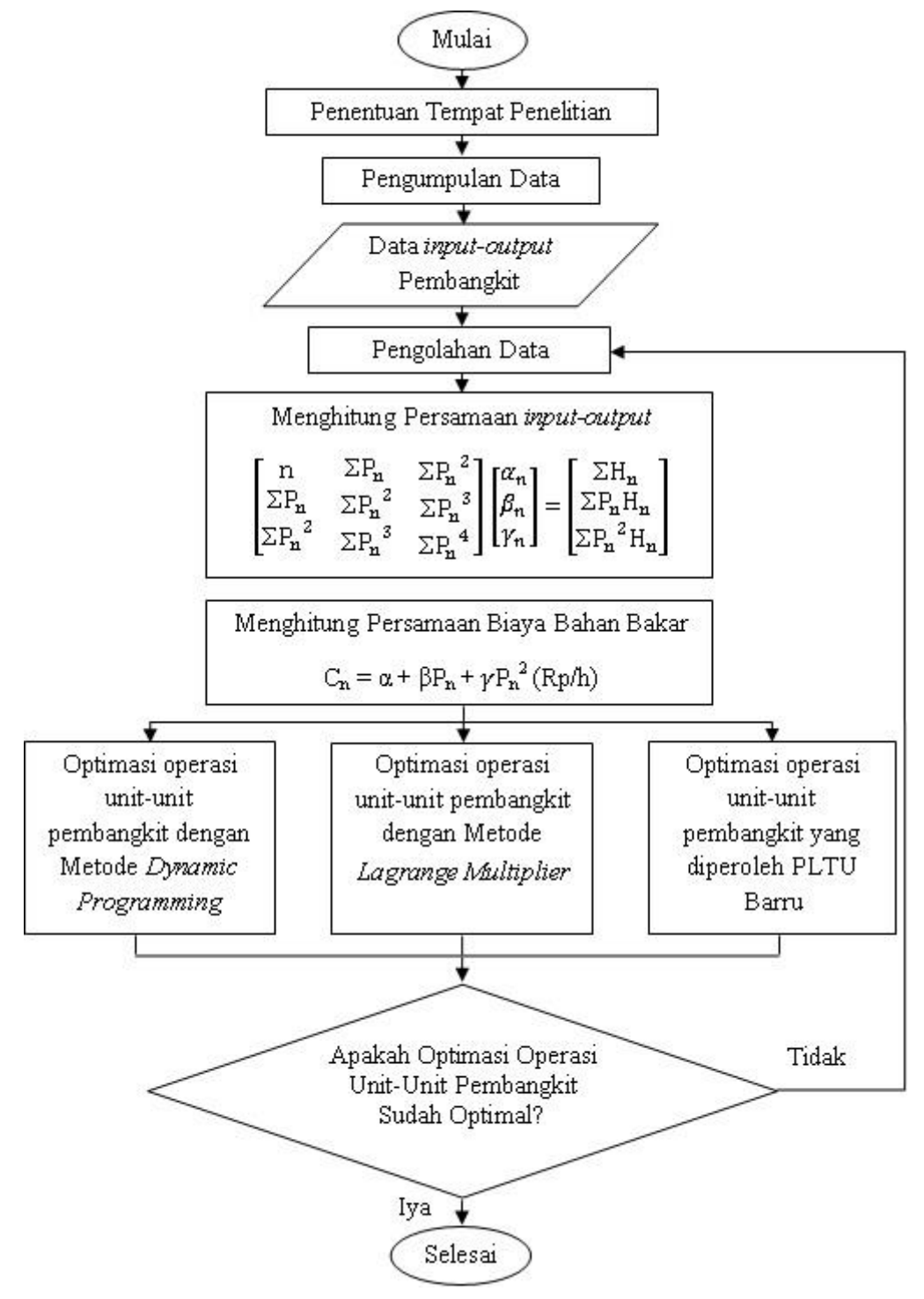

Gambar 3. Flowchart penelitian

\section{HASIL DAN PEMBAHASAN}

A. Hasil

1) Data Pengamatan

a) Kapasitas Daya Maksimum dan Daya Minimum pada PLTU Barru

Kapasitas daya maksimum dan daya minimum pada PLTU Barru dapat dilihat pada Tabel 1.

Tabel 1. Kapasitas Daya Maksimum dan Minimum pada PLTU Barru

\begin{tabular}{|c|c|c|c|c|}
\hline \multirow{2}{*}{ No. } & \multirow{2}{*}{ Unit Pembangkit } & \multicolumn{3}{|c|}{ Daya (MW) } \\
\cline { 3 - 5 } & & Terpasang & Maksimal & Minimal \\
\hline 1 & PLTU Barru Unit 1 & 50 & 50 & 5 \\
\hline 2 & PLTU Barru Unit 2 & 50 & 50 & 5 \\
\hline
\end{tabular}

b) Input-Output PLTU Barru 
i) Harian

Dalam penelitian ini data input-output PLTU Barru yang akan dijadikan sampel ialah data harian pada tanggal 05 Mei 2016.

Tabel 2. Data Input-Output PLTU Barru pada Tanggal 05 Mei 2016

\begin{tabular}{|c|c|c|c|c|}
\hline \multirow{2}{*}{ Jam } & \multicolumn{2}{|c|}{ Daya (MW) } & \multicolumn{2}{c|}{ Bahan Bakar (T/h) } \\
\cline { 2 - 5 } & Unit 1 & Unit 2 & Unit 1 & Unit 2 \\
\hline $01: 00$ & 32,80 & 15,30 & 25,60 & 16,80 \\
\hline $02: 00$ & 32,80 & 15,70 & 26,40 & 16,40 \\
\hline $03: 00$ & 32,70 & 15,00 & 25,20 & 17,10 \\
\hline $04: 00$ & 32,40 & 15,30 & 25,20 & 19,90 \\
\hline $05: 00$ & 32,50 & 15,00 & 24,90 & 16,50 \\
\hline $06: 00$ & 32,10 & 15,00 & 25,40 & 16,70 \\
\hline $07: 00$ & 32,60 & 15,40 & 25,40 & 17,00 \\
\hline $08: 00$ & 32,70 & 15,90 & 26,00 & 17,10 \\
\hline $09: 00$ & 33,40 & 15,40 & 26,30 & 16,90 \\
\hline $10: 00$ & 33,40 & 21,10 & 26,00 & 21,50 \\
\hline $11: 00$ & 33,20 & 27,10 & 26,80 & 22,70 \\
\hline $12: 00$ & 32,90 & 27,30 & 27,10 & 23,70 \\
\hline $13: 00$ & 32,40 & 27,70 & 26,90 & 23,60 \\
\hline $14: 00$ & 32,30 & 27,10 & 26,10 & 23,70 \\
\hline $15: 00$ & 30,10 & 27,70 & 25,70 & 24,30 \\
\hline $16: 00$ & 30,00 & 27,80 & 25,20 & 23,10 \\
\hline $17: 00$ & 33,10 & 27,30 & 29,20 & 23,00 \\
\hline $18: 00$ & 34,10 & 26,70 & 28,90 & 23,00 \\
\hline $19: 00$ & 34,30 & 28,20 & 28,80 & 23,50 \\
\hline $20: 00$ & 34,30 & 28,20 & 27,80 & 24,70 \\
\hline $21: 00$ & 34,40 & 28,30 & 28,20 & 23,70 \\
\hline $22: 00$ & 34,20 & 28,40 & 28,50 & 24,70 \\
\hline $23: 00$ & 32,30 & 29,50 & 27,70 & 25,70 \\
\hline $24: 00$ & 33,00 & 29,30 & 27,50 & 25,07 \\
\hline $14: 00$ & 32,30 & 27,10 & 26,10 & 23,70 \\
\hline
\end{tabular}

Sumber data : PLTU Barru

2) Hasil Pengolahan Data

a) Menghitung Persamaan Input-Output

Pada Tabel 2 tanggal 05 Mei 2016 Unit 1, Berdasarkan persamaan (10), (11), dan (12) dapat diperoleh persamaan input-output dimana $\mathrm{H}_{1}$ adalah input (pemakaian bahan bakar) unit 1 PLTU Barru dengan satuan T/h, $\mathrm{P}_{1}$ adalah output (daya) unit 1 PLTU Barru dengan satuan MW, dan N adalah jumlah data yang digunakan yang diolah dengan metode regresi kuadrat dengan menggunakan aturan Cramer.

Diketahui :

$$
\begin{array}{ll}
\mathrm{P}_{1} & =788,000 \mathrm{MW} \\
\mathrm{H}_{1} & =640,800 \mathrm{~T} / \mathrm{h} \\
\mathrm{H}_{1} \mathrm{P}_{1} & =21.061,660 \mathrm{MWT} / \mathrm{h} \\
\mathrm{P}_{1}{ }^{2} & =25.900,960 \mathrm{MW} \\
\mathrm{P}_{1}{ }^{3} & =852.243,878 \mathrm{MW} \\
\mathrm{P}_{1}{ }^{4} & =28.070 .805,632 \mathrm{MW} \\
\mathrm{H}_{1} \mathrm{P}_{1}^{2}=693.000,904 \mathrm{MW}
\end{array}
$$


70 Remigius Tandioga, Musrady Mulyadi, Azwar, Widya Wirawati Rauf. Optimasi Operasi Unit-Unit Pembangkit Pada PLTU Barru

$\mathrm{N}=24$

Sehingga, untuk PLTU Barru Unit 1 pada tanggal 05 Mei 2016 diperoleh persamaan inputoutput adalah $\mathrm{H}_{1(\mathrm{~T} 5)}=253,125-14,836 \mathrm{P}_{1}+0,242 \mathrm{P}_{1}^{2}(\mathrm{~T} / \mathrm{h})$. Adapun perhitungan persamaan input-output harian pada tanggal 05 Mei 2016 dengan menggunakan Program Matlab dapat dilihat pada Gambar 4.

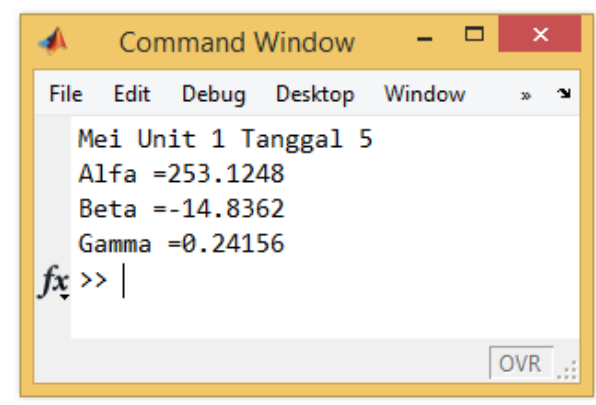

Gambar 4. Persamaan Input-Output pada Tanggal 05 Mei 2016 Menggunakan Program Matlab.

Tabel 3. Persamaan Input-Output Harian PLTU Barru pada Unit 1

\begin{tabular}{|c|c|c|}
\hline \multirow{2}{*}{ Tgl } & \multicolumn{2}{|c|}{ Persamaan Input-Output (T/h) } \\
\hline & Microsoft Office Excel 2007 & Program Matlab \\
\hline 1 & $-30,681+2,852 \mathrm{P}_{1}-0,033 \mathrm{P}_{1}{ }^{2}$ & $-30,6807+2,8519 P_{1}-0,032661 P_{1}{ }^{2}$ \\
\hline 2 & $1.051,189-59,790 P_{1}+0,873 P_{1}{ }^{2}$ & $1.051,1935-59,7856 \mathrm{P}_{1}+0,87342 \mathrm{P}_{1}{ }^{2}$ \\
\hline 3 & $607,064-34,828 P_{1}+0,522 P_{1}{ }^{2}$ & $607,0594-34,828 P_{1}+0,52247 P_{1}^{2}$ \\
\hline 4 & $-21,931+2,332 P_{1}-0,027 P_{1}^{2}$ & $-21,9305+2,3318 P_{1}-0,027295 P_{1}{ }^{2}$ \\
\hline 5 & $253,125-14,836 \mathrm{P}_{1}+0,242 \mathrm{P}_{1}{ }^{2}$ & $253,1248-14,8362 P_{1}+0,24156 P_{1}{ }^{2}$ \\
\hline 6 & $140,275-7,316 P_{1}+0,118 P_{1}{ }^{2}$ & $140,2747-7,3161 P_{1}+0,11847 P_{1}^{2}$ \\
\hline 7 & $-5,376+1,784 P_{1}-0,023 P_{1}^{2}$ & $-5,376+1,7835 P_{1}-0,02282 P_{1}^{2}$ \\
\hline 8 & $10,477+0,488 P_{1}+0,0013 P_{1}{ }^{2}$ & $10,4771+0,48822 P_{1}+0,0012929 P_{1}{ }^{2}$ \\
\hline 9 & - & - \\
\hline 10 & $-80,779+6,390 P_{1}-0,095 P_{1}{ }^{2}$ & $-80,779+6,390 P_{1}-0,094804 P_{1}{ }^{2}$ \\
\hline 11 & $-0,073+0,865 P_{1}-0,000832 P_{1}^{2}$ & $-0,073404+0,86508 P_{1}-0,00083193 P_{1}^{2}$ \\
\hline 12 & - & - \\
\hline 13 & - & - \\
\hline 14 & - & - \\
\hline 15 & - & - \\
\hline 16 & - & - \\
\hline 17 & - & - \\
\hline 18 & $9,543+0,498 P_{1}-0,000242 P_{1}{ }^{2}$ & $9,5432+0,49849 P_{1}-0,00024192 P_{1}^{2}$ \\
\hline 19 & $-53,7335+3,570 P_{1}-0,037 P_{1}^{2}$ & $-53,7335+3,5699 P_{1}-0,036878 P_{1}^{2}$ \\
\hline 20 & $314,708-14,196 P_{1}+0,177 P_{1}^{2}$ & $314,7078-14,1964 P_{1}+0,17697 P_{1}^{2}$ \\
\hline 21 & $-94,347+5,605 P_{1}-0,062 P_{1}^{2}$ & $-94,3469+5,6054 P_{1}-0,062159 P_{1}^{2}$ \\
\hline 22 & $133,276-4,702 P_{1}+0,0549 P_{1}{ }^{2}$ & $133,2757-4,7019 P_{1}+0,054903 P_{1}^{2}$ \\
\hline 23 & $-96,572+5,503 P_{1}-0,058 P_{1}{ }^{2}$ & $-96,5722+5,5033 P_{1}-0,057824 P_{1}^{2}$ \\
\hline 24 & $931,88-39,877 P_{1}+0,442 P_{1}^{2}$ & $931,8804-39,8771 P_{1}+0,44249 P_{1}^{2}$ \\
\hline 25 & $-9,570+1,629 P_{1}-0,015 P_{1}^{2}$ & $-9,5715+1,629 P_{1}-0,014843 P_{1}^{2}$ \\
\hline 26 & $-278,800+13,611 P_{1}-0,148 P_{1}^{2}$ & $-278,7841+13,6109 P_{1}-0,14781 P_{1}{ }^{2}$ \\
\hline 27 & $-775,620+35,3825 P_{1}-0,386 P_{1}{ }^{2}$ & $-775,6218+35,3825 P_{1}-0,38629 P_{1}{ }^{2}$ \\
\hline
\end{tabular}




\begin{tabular}{|l|c|c|}
\hline 28 & $-731,381+33,437 \mathrm{P}_{1}-0,365 \mathrm{P}_{1}{ }^{2}$ & $-731,381+33,4368 \mathrm{P}_{1}-0,36476 \mathrm{P}_{1}{ }^{2}$ \\
\hline 29 & $-700,8+32,376 \mathrm{P}_{1}-0,356 \mathrm{P}_{1}{ }^{2}$ & $-700,7699+32,3764 \mathrm{P}_{1}-0,3564 \mathrm{P}_{1}{ }^{2}$ \\
\hline 30 & $-29,913+2,633 \mathrm{P}_{1}-0,027 \mathrm{P}_{1}{ }^{2}$ & $-29,9129+2,6326 \mathrm{P}_{1}-0,027042 \mathrm{P}_{1}{ }^{2}$ \\
\hline 31 & $-921,6+42,456 \mathrm{P}_{1}-0,471 \mathrm{P}_{1}{ }^{2}$ & $-921,5756+42,4562 \mathrm{P}_{1}-0,47075 \mathrm{P}_{1}{ }^{2}$ \\
\hline
\end{tabular}

Tabel 4. Persamaan Input-Output Harian PLTU Barru pada Unit 2

\begin{tabular}{|c|c|c|}
\hline \multirow{2}{*}{$\operatorname{Tgl}$} & \multicolumn{2}{|c|}{ Persamaan Input-Output $(\mathrm{T} / \mathrm{h})$} \\
\hline & Microsoft Office Excel 2007 & Program Matlab \\
\hline 1 & - & - \\
\hline 2 & - & - \\
\hline 3 & - & - \\
\hline 4 & $0,772+2,113 \mathrm{P}_{2}-0,067 \mathrm{P}_{2}^{2}$ & $0,772+2,113 \mathrm{P}_{2}-0,067 \mathrm{P}_{2}^{2}$ \\
\hline 5 & $9,118+0,522 \mathrm{P}_{2}+0,00033 \mathrm{P}_{2}^{2}$ & $9,1178+0,52237 \mathrm{P}_{2}+0,0003264 \mathrm{P}_{2}^{2}$ \\
\hline 6 & $161,168-10,128 \mathrm{P}_{2}+0,187 \mathrm{P}_{2}{ }^{2}$ & $161,1681-10,1284 \mathrm{P}_{2}+0,18738 \mathrm{P}_{2}^{2}$ \\
\hline 7 & $7,943+0,494 \mathrm{P}_{2}+0,003 \mathrm{P}_{2}^{2}$ & $7,94293+0,49368 \mathrm{P}_{2}+0,003433 \mathrm{P}_{2}^{2}$ \\
\hline 8 & $501,666-33,931 \mathrm{P}_{2}+0,603 \mathrm{P}_{2}^{2}$ & $501,6662-33,9311 \mathrm{P}_{2}+0,60296 \mathrm{P}_{2}^{2}$ \\
\hline 9 & $36,323-0,904 \mathrm{P}_{2}+0,017 \mathrm{P}_{2}^{2}$ & $36,3233-0,90385 \mathrm{P}_{2}+0,017107 \mathrm{P}_{2}^{2}$ \\
\hline 10 & $5,605+1,658 \mathrm{P}_{2}-0,036 \mathrm{P}_{2}^{2}$ & $5,605+1,658 \mathrm{P}_{2}-0,036 \mathrm{P}_{2}^{2}$ \\
\hline 11 & $0,051+1,671 \mathrm{P}_{2}-0,028 \mathrm{P}_{2}^{2}$ & $0,050631+1,6706 \mathrm{P}_{2}-0,028041 \mathrm{P}_{2}^{2}$ \\
\hline 12 & $-30,698+3,725 \mathrm{P}_{2}-0,063 \mathrm{P}_{2}{ }^{2}$ & $-30,698+3,725 \mathrm{P}_{2}-0,063 \mathrm{P}_{2}^{2}$ \\
\hline 13 & - & - \\
\hline 14 & $9,752+0,553 \mathrm{P}_{2}+0,000426 \mathrm{P}_{2}^{2}$ & $9,752+0,553 \mathrm{P}_{2}+0,000426 \mathrm{P}_{2}^{2}$ \\
\hline 15 & $106,783-6,835 \mathrm{P}_{2}+0,140 \mathrm{P}_{2}^{2}$ & $106,783-6,8354 \mathrm{P}_{2}+0,14044 \mathrm{P}_{2}^{2}$ \\
\hline 16 & $73,685-3,959 \mathrm{P}_{2}+0,079 \mathrm{P}_{2}{ }^{2}$ & $73,6853-3,9593 \mathrm{P}_{2}+0,078978 \mathrm{P}_{2}^{2}$ \\
\hline 17 & $-510,53+40,979 \mathrm{P}_{2}-0,785 \mathrm{P}_{2}{ }^{2}$ & $-510,5287+40,9791 \mathrm{P}_{2}-0,78458 \mathrm{P}_{2}^{2}$ \\
\hline 18 & $79,959-4,396 \mathrm{P}_{2}+0,087 \mathrm{P}_{2}{ }^{2}$ & $79,9586-4,3958 \mathrm{P}_{2}+0,087112 \mathrm{P}_{2}^{2}$ \\
\hline 19 & $98,945-5,198 \mathrm{P}_{2}+0,094 \mathrm{P}_{2}{ }^{2}$ & $98,9451-5,1978 \mathrm{P}_{2}+0,093662 \mathrm{P}_{2}^{2}$ \\
\hline 20 & $111,122-5,747 \mathrm{P}_{2}+0,098 \mathrm{P}_{2}{ }^{2}$ & $111,1223-5,7467 \mathrm{P}_{2}+0,098013 \mathrm{P}_{2}{ }^{2}$ \\
\hline 21 & $53,839-2,112 \mathrm{P}_{2}+0,041 \mathrm{P}_{2}{ }^{2}$ & $53,8388-2,1121 \mathrm{P}_{2}+0,041611 \mathrm{P}_{2}^{2}$ \\
\hline 22 & $21,658-0,621 \mathrm{P}_{2}+0,024 \mathrm{P}_{2}^{2}$ & $21,658-0,621 \mathrm{P}_{2}+0,024 \mathrm{P}_{2}^{2}$ \\
\hline 23 & - & - \\
\hline 24 & - & - \\
\hline 25 & $2,917+2,030 \mathrm{P}_{2}-0,063 \mathrm{P}_{2}^{2}$ & $2,917+2,030 \mathrm{P}_{2}-0,063 \mathrm{P}_{2}^{2}$ \\
\hline 26 & $7,772+0,626 \mathrm{P}_{2}+0,001 \mathrm{P}_{2}^{2}$ & $7,7724+0,62565 \mathrm{P}_{2}+0,0013422 \mathrm{P}_{2}^{2}$ \\
\hline 27 & $114,526-5,097 \mathrm{P}_{2}+0,078 \mathrm{P}_{2}^{2}$ & $114,5259-5,0973 \mathrm{P}_{2}+0,077674 \mathrm{P}_{2}^{2}$ \\
\hline 28 & $66,2225-2,544 \mathrm{P}_{2}+0,044 \mathrm{P}_{2}^{2}$ & $66,2225-2,5441 \mathrm{P}_{2}+0,043739 \mathrm{P}_{2}^{2}$ \\
\hline 29 & $1.028,550-51,759 \mathrm{P}_{2}+0,672 \mathrm{P}_{2}{ }^{2}$ & $1.028,5516-51,7593 \mathrm{P}_{2}+0,67233 \mathrm{P}_{2}^{2}$ \\
\hline 30 & $-252,257+14,438 \mathrm{P}_{2}-0,182 \mathrm{P}_{2}{ }^{2}$ & $-252,2567+14,4376 \mathrm{P}_{2}-0,18195 \mathrm{P}_{2}^{2}$ \\
\hline 31 & $-181,792+10,603 \mathrm{P}_{2}-0,129 \mathrm{P}_{2}^{2}$ & $-181,7914+10,6025 \mathrm{P}_{2}-0,12887 \mathrm{P}_{2}^{2}$ \\
\hline
\end{tabular}

b) Menghitung Biaya Bahan Bakar PLTU Barru

Pada PLTU Barru menggunakan bahan bakar batubara dengan biaya per tonnya sebesar Rp. $350.000,-$. sehingga persamaan biaya bahan bakar diperoleh dengan mengalikan persamaan inputoutput masing-masing unit dengan biaya bahan bakar.

Untuk persamaan input-output harian unit 1 pada tanggal 05 Mei 2016 yaitu $\mathrm{H}_{1(\mathrm{~T} 5)}=253,1248$ $14,8362 \mathrm{P}_{1}+0,24156 \mathrm{P}_{1}^{2}(\mathrm{~T} / \mathrm{h})$, dengan biaya bahan bakar per tonnya sebesar Rp. 350.000,-. Maka diperoleh persamaan biaya bahan bakar: 
72 Remigius Tandioga, Musrady Mulyadi, Azwar, Widya Wirawati Rauf. Optimasi Operasi Unit-Unit Pembangkit Pada PLTU Barru

$\mathrm{C}_{1(\mathrm{~T} 5)}=\left(253,1248-14,8362 \mathrm{P}_{1}+0,24156 \mathrm{P}_{1}^{2}\right) \times \mathrm{Rp} .350 .000,-$ $=8,859-0,519 \mathrm{P}_{1}+0,00845 \mathrm{P}_{1}^{2}\left(\mathrm{x} 10^{7} \mathrm{Rp} / \mathrm{h}\right)$

Tabel 5. Persamaan Biaya Bahan Bakar Harian PLTU Barru pada Bulan Mei 2016

\begin{tabular}{|c|c|c|}
\hline Tgl & $\begin{array}{l}\text { Persamaan Biaya Bahan Bakar Unit } 1 \\
\left(\mathrm{x} 10^{7} \mathrm{Rp} / \mathrm{h}\right)\end{array}$ & $\begin{array}{l}\text { Persamaan Biaya Bahan Bakar Unit } 2 \\
\left(\text { (x } 10^{7} \mathrm{Rp} / \mathrm{h}\right)\end{array}$ \\
\hline 1 & $-1,074+0,100 \mathrm{P}_{1}-0,00114 \mathrm{P}_{1}^{2}$ & - \\
\hline 2 & $36,792-2,092 \mathrm{P}_{1}+0,0306 \mathrm{P}_{1}^{2}$ & - \\
\hline 3 & $21,247-1,219 \mathrm{P}_{1}+0,0183 \mathrm{P}_{1}^{2}$ & - \\
\hline 4 & $-0,768+0,082 \mathrm{P}_{1}-0,000955 \mathrm{P}_{1}^{2}$ & $0,027+0,074 \mathrm{P}_{2}-0,00235 \mathrm{P}_{2}^{2}$ \\
\hline 5 & $8,859-0,519 \mathrm{P}_{1}+0,00845 \mathrm{P}_{1}^{2}$ & $0,319+0,018 \mathrm{P}_{2}+0,0000114 \mathrm{P}_{2}^{2}$ \\
\hline 6 & $4,910-0,256 \mathrm{P}_{1}+0,00415 \mathrm{P}_{1}^{2}$ & $5,641-0,354 \mathrm{P}_{2}+0,00656 \mathrm{P}_{2}^{2}$ \\
\hline 7 & $-0,188+0,062 \mathrm{P}_{1}-0,00080 \mathrm{P}_{1}^{2}$ & $0,278-0,017 \mathrm{P}_{2}+0,00012 \mathrm{P}_{2}{ }^{2}$ \\
\hline 8 & $0,367+0,017 \mathrm{P}_{1}+0,0000453 \mathrm{P}^{2}$ & $17,558-1,188 \mathrm{P}_{2}+0,02111 \mathrm{P}_{2}{ }^{2}$ \\
\hline 9 & - & $1,271-0,032 \mathrm{P}_{2}+0,000599 \mathrm{P}_{2}{ }^{2}$ \\
\hline 10 & $-2,827+0,224 \mathrm{P}_{1}-0,00332 \mathrm{P}_{1}^{2}$ & $0,196+0,058 \mathrm{P}_{2}-0,00126 \mathrm{P}_{2}^{2}$ \\
\hline 11 & $-0,003+0,030 \mathrm{P}_{1}-0,0000291 \mathrm{P}_{1}^{2}$ & $0,002+0,058 \mathrm{P}_{2}-0,000981 \mathrm{P}_{2}^{2}$ \\
\hline 12 & - & $-1,074+0,130 \mathrm{P}_{2}-0,00221 \mathrm{P}_{2}{ }^{2}$ \\
\hline 13 & - & - \\
\hline 14 & - & $0,341+0,019 \mathrm{P}_{2}+0,0000149 \mathrm{P}_{2}^{2}$ \\
\hline 15 & - & $3,737-0,239 \mathrm{P}_{2}+0,00492 \mathrm{P}_{2}^{2}$ \\
\hline 16 & - & $2,579-0,139 \mathrm{P}_{2}+0,00276 \mathrm{P}_{2}^{2}$ \\
\hline 17 & - & $-17,869+1,434 \mathrm{P}_{2}-0,02746 \mathrm{P}_{2}^{2}$ \\
\hline 18 & $0,334+0,017 \mathrm{P}_{1}-0,00000847 \mathrm{P}_{1}^{2}$ & $2,799-0,154 \mathrm{P}_{2}+0,00305 \mathrm{P}_{2}^{2}$ \\
\hline 19 & $-1,881+0,125 \mathrm{P}_{1}-0,00129 \mathrm{P}_{1}^{2}$ & $3,463-0,182 \mathrm{P}_{2}+0,00328 \mathrm{P}_{2}^{2}$ \\
\hline 20 & $11,015-0,497 \mathrm{P}_{1}-0,006194 \mathrm{P}_{1}^{2}$ & $3,889-0,201 \mathrm{P}_{2}+0,00343 \mathrm{P}_{2}{ }^{2}$ \\
\hline 21 & $-3,302+0,196 \mathrm{P}_{1}-0,00218 \mathrm{P}_{1}^{2}$ & $1,884-0,074 \mathrm{P}_{2}+0,00146 \mathrm{P}_{2}{ }^{2}$ \\
\hline 22 & $4,665-0,165 \mathrm{P}_{1}+0,0019 \mathrm{P}_{1}{ }^{2}$ & $0,758-0,022 \mathrm{P}_{2}+0,000840 \mathrm{P}_{2}^{2}$ \\
\hline 23 & $-3,380+0,193 \mathrm{P}_{1}-0,00202 \mathrm{P}_{1}^{2}$ & - \\
\hline 24 & $32,616-1,396 \mathrm{P}_{1}+0,0155 \mathrm{P}_{1}{ }^{2}$ & - \\
\hline 25 & $-0,335+0,057 \mathrm{P}_{1}-0,00052 \mathrm{P}_{1}{ }^{2}$ & $0,102+0,071 \mathrm{P}_{2}-0,00221 \mathrm{P}_{2}^{2}$ \\
\hline 26 & $-9,757+0,476 \mathrm{P}_{1}-0,00517 \mathrm{P}_{1}^{2}$ & $0,272+0,022 \mathrm{P}_{2}+0,000047 \mathrm{P}_{2}^{2}$ \\
\hline 27 & $-27,147+1,238 \mathrm{P}_{1}-0,0135 \mathrm{P}_{1}^{2}$ & $4,008-0,178 \mathrm{P}_{2}+0,00272 \mathrm{P}_{2}^{2}$ \\
\hline 28 & $-25,598+1,170 \mathrm{P}_{1}-0,0128 \mathrm{P}_{1}^{2}$ & $2,318-0,089 \mathrm{P}_{2}+0,00153 \mathrm{P}_{2}^{2}$ \\
\hline 29 & $-24,527+1,133 \mathrm{P}_{1}-0,0125 \mathrm{P}_{1}^{2}$ & $35,999-1,812 \mathrm{P}_{2}+0,02353 \mathrm{P}_{2}{ }^{2}$ \\
\hline 30 & $-1,047+0,092 \mathrm{P}_{1}-0,000946 \mathrm{P}_{1}^{2}$ & $-8,829+0,505 \mathrm{P}_{2}-0,00637 \mathrm{P}_{2}^{2}$ \\
\hline 31 & $-32,255+1,486 \mathrm{P}_{1}-0,0165 \mathrm{P}_{1}^{2}$ & $-6,363+0,371 \mathrm{P}_{2}-0,00451 \mathrm{P}_{2}{ }^{2}$ \\
\hline
\end{tabular}

c) Menghitung Biaya Bahan Bakar PLTU Barru

i) Secara Aktual

Berdasarkan Tabel 2. tanggal 05 Mei 2016 jam 01:00, maka dapat diperoleh biaya bahan bakar PLTU Barru sebagai berikut :

Penyelesaian :

$\begin{aligned} \mathrm{C}_{1(\mathrm{~T} 5 \mathrm{j} 1) \text { Aktual }} & =25,60 \mathrm{~T} / \mathrm{h} \times 350.000(\mathrm{Rp} / \mathrm{T}) \\ & =0,896\left(\times 10^{7} \mathrm{Rp} / \mathrm{h}\right) \\ \mathrm{C}_{2(\mathrm{~T} 5 \mathrm{j} 1) \text { Aktual }} & =16,80 \mathrm{~T} / \mathrm{h} \times 350.000(\mathrm{Rp} / \mathrm{T}) \\ & =0,588\left(\times 10^{7} \mathrm{Rp} / \mathrm{h}\right) \\ \mathrm{C}_{\text {Total(T5j1)Aktual }} & =0,896\left(\times 10^{7} \mathrm{Rp} / \mathrm{h}\right)+0,588\left(\times 10^{7} \mathrm{Rp} / \mathrm{h}\right)\end{aligned}$ 


$$
=1,484\left(\mathrm{x} 10^{7} \mathrm{Rp} / \mathrm{h}\right)
$$

Jadi biaya bahan bakar yang telah dikeluarkan oleh PLTU Barru secara aktual pada tanggal 05 Mei 2016 jam 01:00 sebesar Rp 1,484 x 107/h.

ii) Secara Teoritis

Berdasarkan Tabel 2. tanggal 05 Mei 2016 jam 01:00 dan Tabel 6. tanggal 05 Mei 2016, maka dapat diperoleh biaya bahan bakar PLTU Barru berdasarkan hasil perhitungan dengan menggunakan aturan Cramer.

Penyelesaian :

$$
\begin{aligned}
\mathrm{C}_{1(\mathrm{~T} 5 \mathrm{j} 1)} & =8,859-0,519(32,80)+0,00845(32,80)^{2} \\
& =0,927\left(\times 10^{7} \mathrm{Rp} / \mathrm{h}\right) \\
\mathrm{C}_{2(\mathrm{~T} 5 \mathrm{j} 1)} & =0,319+0,018(15,30)+0,0000114(15,30)^{2} \\
& =0,597\left(\times 10^{7} \mathrm{Rp} / \mathrm{h}\right) \\
\mathrm{C}_{\text {Total(T5j1) }} & =0,927\left(\times 10^{7} \mathrm{Rp} / \mathrm{h}\right)+0,597\left(\times 10^{7} \mathrm{Rp} / \mathrm{h}\right) \\
& =1,524\left(\times 10^{7} \mathrm{Rp} / \mathrm{h}\right)
\end{aligned}
$$

Jadi biaya bahan bakar yang telah dikeluarkan oleh PLTU Barru secara teoritis pada tanggal 05 Mei 2016 jam 01:00 sebesar Rp 1,524 x 107/h.

Tabel 6. Hasil Perhitungan Biaya Bahan Bakar PLTU Barru pada Tanggal 05 Mei 2016

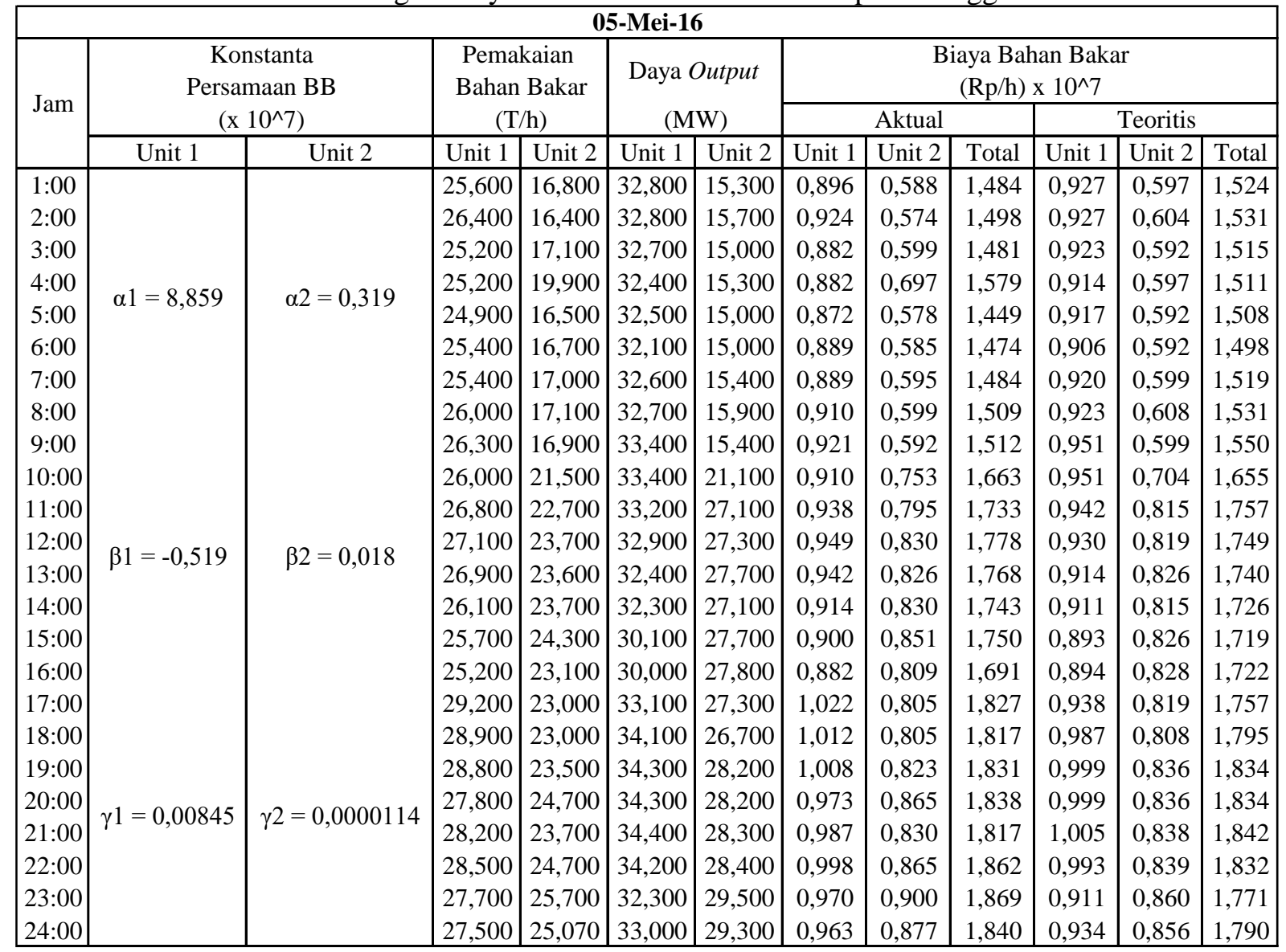

d) Menghitung Biaya Bahan Bakar dengan Metode Lagrange Multiplier

Pada Tabel 6. tanggal 05 Mei 2016 jam 01:00, Berdasarkan persamaan (5) dapat diperoleh biaya bahan bakar yang diolah menggunakan metode Lagrange multiplier:

Penyelesaian : 
74 Remigius Tandioga, Musrady Mulyadi, Azwar, Widya Wirawati Rauf. Optimasi Operasi Unit-Unit Pembangkit Pada PLTU Barru

$$
\begin{aligned}
& \frac{\mathrm{dC}_{1}}{\mathrm{dP}_{1}}=\frac{\mathrm{dC}_{2}}{\mathrm{dP}_{2}} \\
& -0,519+0,0169 \mathrm{P}_{1}=0,018+0,0000228 \mathrm{P}_{2} \\
& -0,519+0,0169 \mathrm{P}_{1}=0,018+0,0000228\left(48,1-\mathrm{P}_{1}\right) \\
& 0,0169228 \mathrm{P}_{1}=0,53809668 \\
& \mathrm{P}_{1}=31,797 \mathrm{MW} \\
& \mathrm{P}_{1}+\mathrm{P}_{2}=48,1 \mathrm{MW} \\
& \mathrm{P}_{2}=48,1 \mathrm{MW}-31,797 \mathrm{MW} \\
& \mathrm{P}_{2}=16,303 \mathrm{MW} \\
& \mathrm{C}_{1(\mathrm{LMT} 5 \mathrm{j} 1)}=8,859-0,519(31,797)+0,00845(31,797)^{2} \\
& =0,8997\left(\mathrm{x} 10^{7} \mathrm{Rp} / \mathrm{h}\right) \\
& \mathrm{C}_{2(\mathrm{LMTSj} 1)}=0,319+0,018(16,303)+0,0000114(16,303)^{2}=0,0,6155\left(\mathrm{x} \mathrm{10} 0^{7} \mathrm{Rp} / \mathrm{h}\right) \\
& \mathrm{C}_{\text {Total(LMT5j1) }}=0,918528\left(\times 10^{7} \mathrm{Rp} / \mathrm{h}\right)+0,616906\left(\times 10^{7} \mathrm{Rp} / \mathrm{h}\right)=1,5152\left(\times 10^{7} \mathrm{Rp} / \mathrm{h}\right)
\end{aligned}
$$

\begin{tabular}{|c|c|c|c|c|c|c|c|c|c|c|c|}
\hline \multirow{3}{*}{ Jam } & \multirow{3}{*}{$\begin{array}{l}\text { Total } \\
\text { Daya } \\
\text { (MW) }\end{array}$} & \multicolumn{5}{|c|}{ Microsoft Office Excel 2007} & \multicolumn{5}{|c|}{ Program Matlab } \\
\hline & & P1 & $\mathrm{P} 2$ & $\mathrm{C}_{1}$ & $\mathrm{C}_{2}$ & $\mathrm{C}_{\mathrm{T}}$ & P1 & $\mathrm{P} 2$ & $\mathrm{C}_{1}$ & $\mathrm{C}_{2}$ & $C_{T}$ \\
\hline & & \multicolumn{2}{|c|}{ (MW) } & \multicolumn{3}{|c|}{$\left(x 10^{7} \mathrm{Rp} / \mathrm{h}\right)$} & \multicolumn{2}{|c|}{$(\mathrm{MW})$} & \multicolumn{3}{|c|}{ (x $\left.10^{7} \mathrm{Rp} / \mathrm{h}\right)$} \\
\hline 01:00 & 48,100 & 31,797 & 16,303 & 0,89973 & 0,61548 & 1,51521 & 31,7971 & 16,3029 & 0,89973 & 0,61548 & 1,5152 \\
\hline $02: 00$ & 48,500 & 31,798 & 16,702 & 0,89974 & 0,62282 & 1,52256 & 31,7977 & 16,7023 & 0,89974 & 0,62282 & 1,5226 \\
\hline 03:00 & 47,700 & 31,797 & 15,903 & 0,89972 & 0,60814 & 1,50786 & 31,7966 & 15,9034 & 0,89972 & 0,60814 & 1,5079 \\
\hline $04: 00$ & 47,700 & 31,797 & 15,903 & 0,89972 & 0,60814 & 1,50786 & 31,7966 & 15,9034 & 0,89972 & 0,60814 & 1,5079 \\
\hline $05: 00$ & 47,500 & 31,796 & 15,704 & 0,89971 & 0,60448 & 1,50419 & 31,7963 & 15,7037 & 0,89971 & 0,60448 & 1,5042 \\
\hline & & & 15,304 & 0,89970 & 0,59715 & 1,49685 & 31, & 15,3042 & 0,8997 & 0,59715 & 1,4968 \\
\hline 07:00 & & 31,797 & 16,203 & 0,89972 & 0,61365 & 1,51337 & 31,797 & 16,203 & 0,89972 & 0,61365 & 1,5134 \\
\hline 08:00 & 600 & 31,798 & 16,802 & 0,89974 & 0,62466 & 1,52440 & 31,7978 & 16,8022 & 0,89974 & 0,62466 & 1,5244 \\
\hline 09:00 & 48,800 & 31,798 & 17,002 & 0,89974 & 0,62833 & 1,52807 & 31,7981 & 17,0019 & 0,89974 & 0,62833 & 1,5281 \\
\hline 10:00 & 54,500 & 31,806 & 22,694 & 0,89988 & 0,73337 & 1,63325 & 31,8058 & 22,6942 & 0,89988 & 0,73337 & 1,6333 \\
\hline $11: 00$ & 60,300 & 31,814 & 28,486 & 0,90003 & 0,84101 & 1,74104 & 31,8136 & 28,4864 & 0,90003 & 0,84101 & 1,741 \\
\hline $12: 00$ & 60,200 & 31,813 & 28,387 & 0,90003 & 0,83914 & 1,73917 & 31,8134 & 28,3866 & 0,90003 & 0,83914 & 1,7392 \\
\hline
\end{tabular}

Jadi biaya bahan bakar harian pada tanggal 05 Mei 2016 jam 01:00 dengan menggunakan metode Lagrange multiplier sebesar Rp $1,5152 \times 10^{7} / \mathrm{h}$. Adapun perhitungan biaya bahan bakar harian dengan metode Lagrange multiplier pada tanggal 05 Mei 2016 jam 01:00 menggunakan Program Matlab dapat dilihat pada Gambar 5.

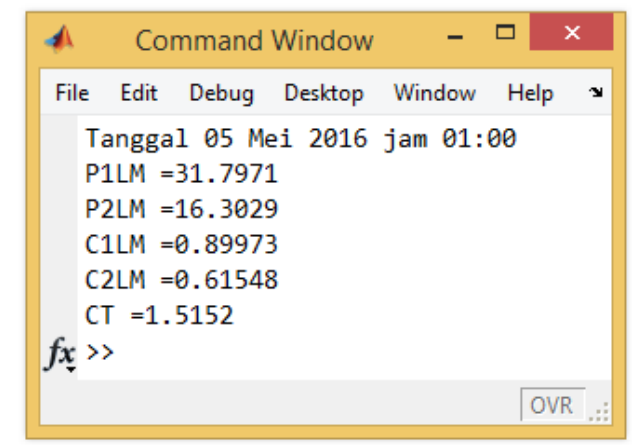

Gambar 5. Perhitungan Biaya Bahan Bakar Harian Tanggal 05 Mei 2016 Jam 01:00 Metode Lagrange Multiplier dengan Menggunakan Program Matlab

Tabel 7. Hasil Perhitungan Biaya Bahan Bakar Harian Metode Lagrange Multiplier PLTU Barru pada Bulan Mei 2016 


\begin{tabular}{|c|c|c|c|c|c|c|c|c|c|c|c|}
\hline 13:00 & 60,100 & 31,813 & 28,287 & 0,90002 & 0,83728 & 1,73731 & 31,8133 & 28,2867 & 0,90002 & 0,83728 & 1,7373 \\
\hline $14: 00$ & 59,400 & 31,812 & 27,588 & 0,90001 & 0,82425 & 1,72426 & 31,8124 & 27,5876 & 0,90001 & 0,82425 & 1,7243 \\
\hline $15: 00$ & 57,800 & 31,810 & 25,990 & 0,89997 & 0,79452 & 1,69448 & 31,8102 & 25,9898 & 0,89997 & 0,79452 & 1,6945 \\
\hline $16: 00$ & 57,800 & 31,810 & 25,990 & 0,89997 & 0,79452 & 1,69448 & 31,8102 & 25,9898 & 0,89997 & 0,79452 & 1,6945 \\
\hline $17: 00$ & 60,400 & 31,814 & 28,586 & 0,90003 & 0,84287 & 1,74290 & 31,8137 & 28,5863 & 0,90003 & 0,84287 & 1,7429 \\
\hline $21: 00$ & 62,700 & 31,817 & 30,883 & 0,90009 & 0,88577 & 1,78586 & 31,8168 & 30,8832 & 0,90009 & 0,88577 & 1,7859 \\
\hline $22: 00$ & 62,600 & 31,817 & 30,783 & 0,90009 & 0,88390 & 1,78399 & 31,8167 & 30,7833 & 0,90009 & 0,8839 & 1,784 \\
\hline $23: 00$ & 61,800 & 31,816 & 29,984 & 0,90007 & 0,86897 & 1,76904 & 31,8156 & 29,9844 & 0,90007 & 0,86897 & 1,769 \\
\hline $24: 00$ & 62,300 & 31,816 & 30,484 & 0,90008 & 0,87830 & 1,77838 & 31,8163 & 30,4837 & 0,90008 & 0,8783 & 1,7784 \\
\hline
\end{tabular}

Ket : $\quad \mathrm{C}_{1(\mathrm{~T} 5)}=8,859-0,519 \mathrm{P}_{1}+0,00845 \mathrm{P}_{1}^{2}\left(\mathrm{x} \mathrm{10} 0^{7} \mathrm{Rp} / \mathrm{h}\right)$

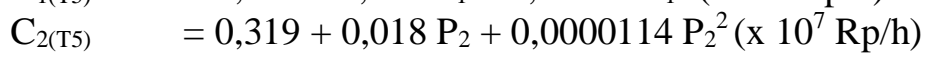

e) Menghitung Biaya Bahan Bakar dengan Metode Dynamic Programming

Pada Tabel 9. tanggal 05 Mei 2016 jam 07:00, Berdasarkan persamaan (18) dapat diperoleh harga bahan bakar yang diolah menggunakan metode dynamic programming.

Tabel 8. Perhitungan Biaya Bahan Bakar Minimum Harian PLTU Barru pada Tanggal 05 Mei 2016

\begin{tabular}{|c|c|c|c|c|c|c|c|c|c|c|c|c|c|c|c|c|c|c|c|c|}
\hline \multicolumn{21}{|c|}{ Tanggal 05 Mei jam 07:00 } \\
\hline \multirow{3}{*}{ No. } & \multirow{3}{*}{$\begin{array}{c}\mathrm{y} \\
(\mathrm{MW})\end{array}$} & \multicolumn{19}{|c|}{ Biaya minimum $: \operatorname{Bn}(x)=\min \{b n(y)+B(n-1)(x-y)\} \quad\left(x 10^{\wedge} 7 \mathrm{Rp} / \mathrm{jam}\right)$} \\
\hline & & \multirow[b]{2}{*}{ Unit 1} & \multicolumn{18}{|c|}{2 Unit } \\
\hline & & & $\mathrm{bn}(\mathrm{y})$ & $\begin{array}{c}48,000 \\
\text { MW }\end{array}$ & $\begin{array}{c}45,000 \\
\text { MW }\end{array}$ & $\begin{array}{c}42,000 \\
\text { MW }\end{array}$ & $\begin{array}{c}39,000 \\
\text { MW }\end{array}$ & $\begin{array}{c}36,000 \\
\text { MW }\end{array}$ & $\begin{array}{c}33,000 \\
\text { MW }\end{array}$ & $\begin{array}{c}30,000 \\
\text { MW }\end{array}$ & $\begin{array}{c}27,000 \\
\text { MW }\end{array}$ & $\begin{array}{c}24,000 \\
\text { MW }\end{array}$ & $\begin{array}{c}21,000 \\
\text { MW }\end{array}$ & $\begin{array}{c}18,000 \\
\text { MW }\end{array}$ & $\begin{array}{c}15,000 \\
\text { MW }\end{array}$ & $\begin{array}{c}12,000 \\
\text { MW }\end{array}$ & $\begin{array}{c}9,000 \\
\text { MW }\end{array}$ & $\begin{array}{l}6,000 \\
\text { MW }\end{array}$ & $\begin{array}{c}3,000 \\
\text { MW }\end{array}$ & $\begin{array}{c}0,000 \\
\text { MW }\end{array}$ \\
\hline 1 & 0,000 & 8,859 & 0,319 & 3,735 & 2,934 & 2,286 & 1,789 & 1,445 & 1,253 & 1,213 & 1,325 & 1,589 & 2,005 & 2,574 & 3,294 & 4,167 & 5,191 & 6,368 & 7,697 & 9,178 \\
\hline 2 & 3,000 & 7,378 & 0,373 & 2,988 & 2,340 & 1,844 & 1,499 & 1,307 & 1,267 & 1,379 & 1,643 & 2,060 & 2,628 & 3,348 & 4,221 & 5,246 & 6,422 & 7,751 & 9,232 & \\
\hline 3 & 6,000 & 6,049 & 0,427 & 2,394 & 1,898 & 1,554 & 1,361 & 1,321 & 1,433 & 1,698 & 2,114 & 2,682 & 3,403 & 4,275 & 5,300 & 6,477 & 7,805 & 9,286 & & \\
\hline 4 & 9,000 & 4,872 & 0,482 & 1,952 & 1,608 & 1,416 & 1,376 & 1,488 & 1,752 & 2,168 & 2,737 & 3,457 & 4,330 & 5,354 & 6,531 & 7,860 & 9,341 & & & \\
\hline 5 & 12,000 & 3,848 & 0,537 & 1,663 & 1,471 & 1,431 & 1,543 & 1,807 & 2,223 & 2,791 & 3,512 & 4,384 & 5,409 & 6,586 & 7,915 & 9,396 & & & & \\
\hline 6 & 15,000 & 2,975 & 0,592 & 1,526 & 1,486 & 1,598 & 1,862 & 2,278 & 2,846 & 3,567 & 4,439 & 5,464 & 6,641 & 7,970 & 9,451 & & & & & \\
\hline 7 & 18,000 & 2,255 & 0,647 & 1,541 & 1,653 & 1,917 & 2,333 & 2,901 & 3,622 & 4,494 & 5,519 & 6,696 & 8,025 & 9,506 & & & & & & \\
\hline 8 & 21,000 & 1,686 & 0,702 & 1,708 & 1,972 & 2,388 & 2,957 & 3,677 & 4,550 & 5,574 & 6,751 & 8,080 & 9,561 & & & & & & & \\
\hline 9 & 24,000 & 1,270 & 0,758 & 2,028 & 2,444 & 3,012 & 3,733 & 4,605 & 5,630 & 6,807 & 8,136 & 9,617 & & & & & & & & \\
\hline 10 & 27,000 & 1,006 & 0,813 & 2,500 & 3,068 & 3,789 & 4,661 & 5,686 & 6,863 & 8,191 & 9,672 & & & & & & & & & \\
\hline 11 & 30,000 & 0,894 & 0,869 & 3,124 & 3,845 & 4,717 & 5,742 & 6,918 & 8,247 & 9,728 & & & & & & & & & & \\
\hline 12 & 33,000 & 0,934 & 0,925 & 3,901 & 4,773 & 5,798 & 6,975 & 8,303 & 9,784 & & & & & & & & & & & \\
\hline 13 & 36,000 & 1,126 & 0,982 & 4,830 & 5,854 & 7,031 & 8,360 & 9,841 & & & & & & & & & & & & \\
\hline 14 & 39,000 & 1,470 & 1,038 & 5,911 & 7,088 & 8,416 & 9,897 & & & & & & & & & & & & & \\
\hline 15 & 42,000 & 1,967 & 1,095 & 7,144 & 8,473 & 9,954 & & & & & & & & & & & & & & \\
\hline 16 & 45,000 & 2,615 & 1,152 & 8,530 & 10,011 & & & & & & & & & & & & & & & \\
\hline 17 & 48,000 & 3,416 & 1,209 & 10,068 & & & & & & & & & & & & & & & & \\
\hline \multicolumn{4}{|c|}{ Biaya minimum } & 1,526 & & & & & & & & & & & & & & & & \\
\hline
\end{tabular}

Jadi pada beban $48 \mathrm{MW}$ didapatkan $\mathrm{P}_{1}=33 \mathrm{MW}, \mathrm{P}_{2}=15 \mathrm{MW}$, dan biaya minimum ialah 1,526 (x 10 $\mathrm{Rp} / \mathrm{h})$.

Tabel 9. Hasil Perhitungan Biaya Bahan Bakar Harian PLTU Barru pada Tanggal 05 Mei 2016 dengan Metode Dynamic Programming

\begin{tabular}{|c|c|c|c|c|c|c|c|c|c|c|c|}
\hline \multirow{3}{*}{ Jam } & \multirow{3}{*}{$\begin{array}{l}\text { Total } \\
\text { Daya } \\
\text { (MW) }\end{array}$} & \multicolumn{5}{|c|}{ Microsoft Office Excel 2007} & \multicolumn{5}{|c|}{ Program Matlab } \\
\hline & & $P_{1}$ & $\mathrm{P}_{2}$ & $\mathrm{C}_{1}$ & $\mathrm{C}_{2}$ & $\mathrm{C}_{T}$ & $P_{1}$ & $\mathrm{P}_{2}$ & $\mathrm{C}_{1}$ & $\mathrm{C}_{2}$ & $\mathrm{C}_{T}$ \\
\hline & & \multicolumn{2}{|c|}{ (MW) } & \multicolumn{3}{|c|}{$\left(\times 10^{7} \mathrm{Rp} / \mathrm{h}\right)$} & \multicolumn{2}{|c|}{ (MW) } & \multicolumn{3}{|c|}{ (x 107 Rp/h) } \\
\hline 01:00 & 48,100 & 31,265 & 16,835 & 0,892 & 0,625 & 1,518 & 31,265 & 16,835 & 0,89234 & 0,62526 & 1,5176 \\
\hline 02:00 & 48,500 & 31,525 & 16,975 & 0,895 & 0,628 & 1,523 & 31,525 & 16,975 & 0,89535 & 0,62783 & 1,5232 \\
\hline 03:00 & 47,700 & 31,005 & 16,695 & 0,890 & 0,623 & 1,513 & 28,620 & 16,695 & 0,89047 & 0,62269 & 1,5132 \\
\hline 04:00 & 47,700 & 31,005 & 16,695 & 0,890 & 0,623 & 1,513 & 28,620 & 16,695 & 0,89047 & 0,62269 & 1,5132 \\
\hline 05:00 & 47,500 & 30,875 & 16,625 & 0,890 & 0,621 & 1,511 & 30,875 & 16,625 & 0,88897 & 0,625 & 1,5114 \\
\hline 06:00 & 47,100 & 32,970 & 14,130 & 0,933 & 0,576 & 1,5085 & 32,97 & 14,13 & 0,9329 & 0,57562 & 1,5085 \\
\hline 07:00 & 48,000 & 33,000 & 15,000 & 0,934 & 0,592 & 1,526 & 33,000 & 15,000 & 0,93405 & 0,59157 & 1,5256 \\
\hline 08:00 & 48,600 & 31,590 & 17,010 & 0,896 & 0,628 & 1,525 & 31,590 & 17,010 & 0,89628 & 0,62848 & 1,5248 \\
\hline 09:00 & 48,800 & 31,720 & 17,080 & 0,898 & 0,630 & 1,528 & 31,72 & 17,08 & 0,89836 & 0,62977 & 1,5281 \\
\hline $10: 00$ & 54,500 & 32,700 & 21,800 & 0,923 & 0,717 & 1,640 & 32,7 & 21,8 & 0,9232 & 0,71682 & 1,64 \\
\hline 11:00 & 60,300 & 33,165 & 27,135 & 0,941 & 0,816 & 1,756 & 33,165 & 27,135 & 0,94067 & 0,81582 & 1,7565 \\
\hline $12: 00$ & 60,200 & 33,110 & 27,090 & 0,938 & 0,815 & 1,753 & 33,110 & 27,09 & 0,93841 & 0,81499 & 1,7534 \\
\hline
\end{tabular}


76 Remigius Tandioga, Musrady Mulyadi, Azwar, Widya Wirawati Rauf. Optimasi Operasi Unit-Unit Pembangkit Pada PLTU Barru

\begin{tabular}{|c|c|c|c|c|c|c|c|c|c|c|c|}
\hline $13: 00$ & 60,100 & 33,055 & 27,045 & 0,936 & 0,814 & 1,750 & 33,055 & 27,045 & 0,9362 & 0,81415 & 1,7504 \\
\hline $14: 00$ & 59,400 & 32,670 & 26,730 & 0,922 & 0,808 & 1,730 & 32,67 & 26,73 & 0,9222 & 0,80829 & 1,7305 \\
\hline $15: 00$ & 57,800 & 31,790 & 26,010 & 0,900 & 0,795 & 1,694 & 31,79 & 26,01 & 0,89959 & 0,79489 & 1,6945 \\
\hline $16: 00$ & 57,800 & 31,790 & 26,010 & 0,900 & 0,795 & 1,694 & 31,79 & 26,01 & 0,89959 & 0,79489 & 1,6945 \\
\hline $17: 00$ & 60,400 & 33,220 & 27,180 & 0,943 & 0,817 & 1,760 & 33,22 & 27,18 & 0,94297 & 0,81666 & 1,7596 \\
\hline $18: 00$ & 60,800 & 30,400 & 30,400 & 0,891 & 0,877 & 1,767 & 30,4 & 30,4 & 0,89055 & 0,87674 & 1,7673 \\
\hline $19: 00$ & 62,500 & 31,250 & 31,250 & 0,892 & 0,893 & 1,785 & 31,25 & 31,25 & 0,8922 & 0,89263 & 1,78548 \\
\hline $20: 00$ & 62,500 & 31,250 & 31,250 & 0,892 & 0,893 & 1,785 & 31,25 & 31,25 & 0,8922 & 0,89263 & 1,78548 \\
\hline $21: 00$ & 62,700 & 31,350 & 31,350 & 0,893 & 0,895 & 1,788 & 31,35 & 31,35 & 0,8932 & 0,8945 & 1,7877 \\
\hline $22: 00$ & 62,600 & 31,300 & 31,300 & 0,893 & 0,894 & 1,786 & 31,3 & 31,3 & 0,89268 & 0,89357 & 1,7862 \\
\hline $23: 00$ & 61,800 & 30,900 & 30,900 & 0,890 & 0,886 & 1,776 & 30,9 & 30,9 & 0,89004 & 0,88608 & 1,7761 \\
\hline $24: 00$ & 62,300 & 31,150 & 31,150 & 0,891 & 0,891 & 1,782 & 31,15 & 31,15 & 0,89138 & 0,89076 & 1,7821 \\
\hline
\end{tabular}

Keterangan : $\mathrm{C}_{1(\mathrm{~T} 5)}=8,859-0,519 \mathrm{P}_{1}+0,00845 \mathrm{P}_{1}^{2}\left(\mathrm{x} \mathrm{10} 0^{7} \mathrm{Rp} / \mathrm{h}\right)$

$$
\mathrm{C}_{2(\mathrm{~T})}=0,319+0,018 \mathrm{P}_{2}+0,0000114 \mathrm{P}_{2}^{2}\left(\mathrm{x} 10^{7} \mathrm{Rp} / \mathrm{h}\right)
$$

\section{B. Pembahasan}

Untuk mendapatkan model operasi yang optimal terhadap setiap unit maka dilakukan perhitungan pengolahan data harian, mingguan, dan bulanan agar menunjukkan biaya bahan bakar minimum dengan daya yang optimum untuk setiap unit pada PLTU Barru dengan perhitungan menggunakan metode Lagrange multiplier dan dynamic programming kemudian dibandingkan dengan biaya bahan bakar yang telah dikeluarkan oleh perusahaan. Adapun hasil perbandingan yang lebih optimal antara kondisi nyata PLTU Barru dan hasil perhitungan.

Tabel 10. Perbandingan yang Lebih Optimal antara Kondisi Nyata PLTU Barru dan Hasil Perhitungan.

\begin{tabular}{|c|c|c|c|}
\hline $\mathrm{Tgl}$ & Kondisi Nyata PLTU Barru Lebih Optimal & Hasil Perhitungan Lebih Optimal & $\begin{array}{l}\text { Kondisi Lain yg } \\
\text { Tdk Jelas }\end{array}$ \\
\hline $\begin{array}{l}4 \text { Mei } \\
2016\end{array}$ & $\begin{array}{c}\text { Jam 17:00 - 24:00 } \\
24,40 \mathrm{MW}(24,40 \%)-48,10 \mathrm{MW}(48,10 \%)\end{array}$ & - & ( \\
\hline $\begin{array}{l}5 \text { Mei } \\
2016\end{array}$ & $\begin{array}{c}\text { Jam 01:00 - 16:00 } \\
\text { 47,10 MW }(47,10 \%)-60,30 \mathrm{MW}(60,30 \%)\end{array}$ & $\begin{array}{c}\text { Jam 17:00 - 24:00 } \\
60,40 \mathrm{MW}(60,40 \%)-62,70 \mathrm{MW}(62,70 \%)\end{array}$ & - \\
\hline $\begin{array}{l}6 \text { Mei } \\
2016 \\
\end{array}$ & $\begin{array}{c}\text { Jam 01:00 - 17:00 } \\
57,90 \mathrm{MW}(57,90 \%)-63,90 \mathrm{MW}(63,90 \%)\end{array}$ & $\begin{array}{c}\text { Jam 18:00 - 24:00 } \\
60,30 \mathrm{MW}(60,30 \%)-61,50 \mathrm{MW}(61,50 \%)\end{array}$ & - \\
\hline $\begin{array}{l}7 \text { Mei } \\
2016\end{array}$ & 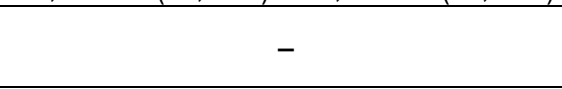 & $\begin{array}{c}\text { Jam 01:00 - 24:00 } \\
50,50 \mathrm{MW}(50,50 \%)-62,90 \mathrm{MW}(62,90 \%)\end{array}$ & - \\
\hline $\begin{array}{l}8 \text { Mei } \\
2016\end{array}$ & $\begin{array}{c}\text { Jam 17:00 - 24:00 } \\
57,28 \mathrm{MW}(57,28 \%)-58,51 \mathrm{MW}(58,51 \%)\end{array}$ & $\begin{array}{c}\text { Jam 01:00 - 16:00 } \\
58,64 \mathrm{MW}(58,64 \%)-64,80 \mathrm{MW}(64,80 \%)\end{array}$ & - \\
\hline $\begin{array}{c}10 \mathrm{Mei} \\
2016\end{array}$ & $\begin{array}{c}\text { Jam 01:00 - 08:00 } \\
55,80 \mathrm{MW}(55,80 \%)-57,60 \mathrm{MW}(57,60 \%)\end{array}$ & 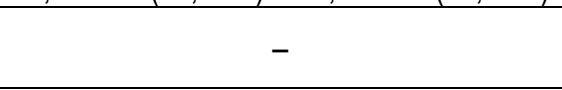 & - \\
\hline $\begin{array}{c}11 \mathrm{Mei} \\
2016 \\
\end{array}$ & $\begin{array}{c}\text { Jam 01:00 - 12:00 } \\
31,40 \mathrm{MW}(31,40 \%)-61,30 \mathrm{MW}(61,40 \%)\end{array}$ & - & - \\
\hline $\begin{array}{c}18 \mathrm{Mei} \\
2016 \\
\end{array}$ & $\begin{array}{c}\text { Jam 07:00 - 08:00 } \\
\text { 30,21 MW }(30,21 \%)-34,88 \mathrm{MW}(34,88 \%)\end{array}$ & $\begin{array}{c}\text { Jam 09:00 - 20:00 } \\
\text { 39,09 MW }(39,09 \%)-70,90 \mathrm{MW}(70,90 \%)\end{array}$ & $\begin{array}{c}\text { Jam 21:00- } \\
24: 00\end{array}$ \\
\hline $\begin{array}{c}19 \mathrm{Mei} \\
2016 \\
\end{array}$ & $\begin{array}{c}\text { Jam 01:00 - 02:00 } \\
68,80 \mathrm{MW}(68,80 \%)-70,20 \mathrm{MW}(70,20 \%)\end{array}$ & $\begin{array}{c}\text { Jam 09:00 - 24:00 } \\
67,47 \mathrm{MW}(67,47 \%)-74 \mathrm{MW}(74 \%)\end{array}$ & $\begin{array}{l}\text { Jam 03:00 - } \\
\text { 08:00 }\end{array}$ \\
\hline $\begin{array}{l}20 \text { Mei } \\
2016\end{array}$ & ( & $\begin{array}{c}\text { Jam 01:00 - 08:00 } \\
66,40 \mathrm{MW}(66,40 \%)-73,80 \mathrm{MW}(73,80 \%)\end{array}$ & $\begin{array}{l}\text { Jam 09:00 - } \\
24: 00\end{array}$ \\
\hline $\begin{array}{c}21 \mathrm{Mei} \\
2016\end{array}$ & - & $\begin{array}{c}\text { Jam 01:00 - 24:00 } \\
65,50 \mathrm{MW}(65,50 \%)-79,50 \mathrm{MW}(79,50 \%)\end{array}$ & 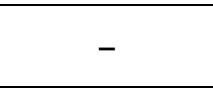 \\
\hline $\begin{array}{c}22 \mathrm{Mei} \\
2016\end{array}$ & $\begin{array}{c}\text { Jam 06:00 } \\
38,18 \mathrm{MW}(38,18 \%)\end{array}$ & $\begin{array}{c}\text { Jam 01:00 - 05:00 } \\
52,50 \mathrm{MW}(52,50 \%)-78,10 \mathrm{MW}(78,10 \%)\end{array}$ & - \\
\hline $\begin{array}{c}25 \mathrm{Mei} \\
2016\end{array}$ & $\begin{array}{c}\text { Jam 21:00 - 22:00 } \\
\text { 49,80 MW (49,80\%) -53,40 MW (53,40\%) }\end{array}$ & $\begin{array}{c}\text { Jam 23:00 } \\
57,60 \mathrm{MW}(57,60 \%)\end{array}$ & - \\
\hline $26 \mathrm{Mei}$ & - & Jam 01:00 - 24:00 & - \\
\hline
\end{tabular}




\begin{tabular}{|c|c|c|c|}
\hline 2016 & & $69,80 \mathrm{MW}(69,80 \%)-85,80 \mathrm{MW}(85,80 \%)$ & \\
\hline $\begin{array}{c}27 \mathrm{Mei} \\
2016\end{array}$ & - & $\begin{array}{c}\operatorname{Jam} 01: 00-24: 00 \\
78,60 \mathrm{MW}(78,60 \%)-86,20 \mathrm{MW}(86,20 \%)\end{array}$ & - \\
\hline $\begin{array}{l}28 \mathrm{Mei} \\
2016\end{array}$ & - & $\begin{array}{c}\operatorname{Jam} 01: 00-24: 00 \\
73,30 \mathrm{MW}(73,30 \%)-88,16 \mathrm{MW}(88,16 \%)\end{array}$ & - \\
\hline $\begin{array}{l}29 \mathrm{Mei} \\
2016\end{array}$ & - & $\begin{array}{c}\text { Jam 01:00 - 24:00 } \\
80,50 \mathrm{MW}(80,50 \%)-86,40 \mathrm{MW}(86,40 \%)\end{array}$ & - \\
\hline $\begin{array}{c}30 \mathrm{Mei} \\
2016\end{array}$ & - & $\begin{array}{c}\operatorname{Jam} 01: 00-24: 00 \\
64,40 \mathrm{MW}(64,40 \%)-87 \mathrm{MW}(87 \%)\end{array}$ & - \\
\hline $\begin{array}{c}31 \mathrm{Mei} \\
2016\end{array}$ & - & $\begin{array}{c}\text { Jam 01:00 - 24:00 } \\
82,10 \mathrm{MW}(82,10 \%)-86 \mathrm{MW}(86 \%)\end{array}$ & - \\
\hline
\end{tabular}

Tabel 11. Perbandingan Biaya Bahan Bakar Harian PLTU Barru dengan Berbagai Metode pada Tanggal 05 Mei 2016.

\begin{tabular}{|c|c|c|c|c|c|c|c|c|c|c|c|c|c|}
\hline \multirow{3}{*}{ Jam } & \multirow{3}{*}{$\begin{array}{l}\text { Total } \\
\text { Daya } \\
\text { (MW) }\end{array}$} & \multicolumn{3}{|c|}{ PLTU Barru Aktual } & \multicolumn{3}{|c|}{$\begin{array}{l}\text { PLTU Barru Teoritis } \\
\text { (Aturan Cramer) }\end{array}$} & \multicolumn{3}{|c|}{ Lagrange Multipliler } & \multicolumn{3}{|c|}{ Dynamic Programming } \\
\hline & & $\mathbf{P}_{1}$ & $\mathrm{P}_{2}$ & $\mathrm{C}_{\mathrm{T}}$ & $\mathbf{P}_{1}$ & $\mathrm{P}_{2}$ & $\mathrm{C}_{\mathrm{T}}$ & $\mathbf{P}_{1}$ & $\mathrm{P}_{2}$ & $\mathrm{C}_{\mathrm{I}}$ & $\mathbf{P}_{1}$ & $\mathrm{P}_{2}$ & $\mathrm{C}_{\mathrm{T}}$ \\
\hline & & \multicolumn{2}{|c|}{ (MW) } & $\begin{array}{l}\text { (x10? } \\
\mathrm{Rp} / \mathrm{h})\end{array}$ & \multicolumn{2}{|c|}{ (MW) } & $\begin{array}{l}\left(\mathrm{x} 10^{7}\right. \\
\mathrm{Rp} / \mathrm{h})\end{array}$ & \multicolumn{2}{|c|}{ (MW) } & $\begin{array}{l}\left(\mathrm{x} 10^{7}\right. \\
\mathrm{Rp} / \mathrm{h})\end{array}$ & \multicolumn{2}{|c|}{ (MW) } & $\begin{array}{l}\left(\mathrm{x} 10^{7}\right. \\
\mathrm{Rp} / \mathrm{h})\end{array}$ \\
\hline $01: 00$ & 48,100 & 32,800 & 15,300 & 1,484 & 32,80 & 15,30 & 1,524 & 31,7971 & 16,3029 & 1,5152 & 31,265 & 16,835 & 1,5176 \\
\hline $02: 00$ & 48,500 & 32,800 & 15,700 & 1,498 & 32,80 & 15,70 & 1,531 & 31,7977 & 16,7023 & 1,5226 & 31,525 & 16,975 & 1,5232 \\
\hline $03: 00$ & 47,700 & 32,700 & 15,000 & 1,481 & 32,70 & 15,00 & 1,515 & 31,7966 & 15,9034 & 1,5079 & 28,620 & 16,695 & 1,5132 \\
\hline $04: 00$ & 47,700 & 32,400 & 15,300 & 1,579 & 32,40 & 15,30 & 1,511 & 31,7966 & 15,9034 & 1,5079 & 28,620 & 16,695 & 1,5132 \\
\hline $05: 00$ & 47,500 & 32,500 & 15,000 & 1,449 & 32,50 & 15,00 & 1,508 & 31,7963 & 15,7037 & 1,5042 & 30,875 & 16,625 & 1,5114 \\
\hline $06: 00$ & 47,100 & 32,100 & 15,000 & 1,474 & 32,10 & 15,00 & 1,498 & 31,7958 & 15,3042 & 1,4968 & 32,97 & 14,13 & 1,5085 \\
\hline $07: 00$ & 48,000 & 32,600 & 15,400 & 1,484 & 32,60 & 15,40 & 1,519 & 31,797 & 16,203 & 1,5134 & 33,000 & 15,000 & 1,5256 \\
\hline $08: 00$ & 48,600 & 32,700 & 15,900 & 1,509 & 32,70 & 15,90 & 1,531 & 31,7978 & 16,8022 & 1,5244 & 31,590 & 17,010 & 1,5248 \\
\hline $09: 00$ & 48,800 & 33,400 & 15,400 & 1,512 & 33,40 & 15,40 & 1,550 & 31,7981 & 17,0019 & 1,5281 & 31,72 & 17,08 & 1,5281 \\
\hline $10: 00$ & 54,500 & 33,400 & 21,100 & 1,663 & 33,40 & 21,10 & 1,655 & 31,8058 & 22,6942 & 1,6333 & 32,7 & 21,8 & 1,64 \\
\hline $11: 00$ & 60,300 & 33,200 & 27,100 & 1,733 & 33,20 & 27,10 & 1,757 & 31,8136 & 28,4864 & 1,741 & 33,165 & 27,135 & 1,7565 \\
\hline $12: 00$ & 60,200 & 32,900 & 27,300 & 1,778 & 32,90 & 27,30 & 1,749 & 31,8134 & 28,3866 & 1,7392 & 33,110 & 27,09 & 1,7534 \\
\hline $13: 00$ & 60,100 & 32,400 & 27,700 & 1,768 & 32,40 & 27,70 & 1,740 & 31,8133 & 28,2867 & 1,7373 & 33,055 & 27,045 & 1,7504 \\
\hline $14: 00$ & 59,400 & 32,300 & 27,100 & 1,743 & 32,30 & 27,10 & 1,726 & 31,8124 & 27,5876 & 1,7243 & 32,67 & 26,73 & 1,7305 \\
\hline $15: 00$ & 57,800 & 30,100 & 27,700 & 1,750 & 30,10 & 27,70 & 1,719 & 31,8102 & 25,9898 & 1,6945 & 31,79 & 26,01 & 1,6945 \\
\hline $16: 00$ & 57,800 & 30,000 & 27,800 & 1,691 & 30,00 & 27,80 & 1,722 & 31,8102 & 25,9898 & 1,6945 & 31,79 & 26,01 & 1,6945 \\
\hline $17: 00$ & 60,400 & 33,100 & 27,300 & 1,827 & 33,10 & 27,30 & 1,757 & 31,8137 & 28,5863 & 1,7429 & 33,22 & 27,18 & 1,7596 \\
\hline $18: 00$ & 60,800 & 34,100 & 26,700 & 1,817 & 34,10 & 26,70 & 1,795 & 31,8143 & 28,9857 & 1,7504 & 30,4 & 30,4 & 1,7673 \\
\hline $19: 00$ & 62,500 & 34,300 & 28,200 & 1,831 & 34,30 & 28,20 & 1,834 & 31,8165 & 30,6835 & 1,7821 & 31,25 & 31,25 & 1,78548 \\
\hline $20: 00$ & 62,500 & 34,300 & 28,200 & 1,838 & 34,30 & 28,20 & 1,834 & 31,8165 & 30,6835 & 1,7821 & 31,25 & 31,25 & 1,78548 \\
\hline $21: 00$ & 62,700 & 34,400 & 28,300 & 1,817 & 34,40 & 28,30 & 1,842 & 31,8168 & 30,8832 & 1,7859 & 31,35 & 31,35 & 1,7877 \\
\hline $22: 00$ & 62,600 & 34,200 & 28,400 & 1,862 & 34,20 & 28,40 & 1,832 & 31,8167 & 30,7833 & 1,784 & 31,3 & 31,3 & 1,7862 \\
\hline $23: 00$ & 61,800 & 32,300 & 29,500 & 1,869 & 32,30 & 29,50 & 1,771 & 31,8156 & 29,9844 & 1,769 & 30,9 & 30,9 & 1,7761 \\
\hline $24: 00$ & 62,300 & 33,000 & 29,300 & 1,840 & 33,00 & 29,30 & 1,790 & 31,8163 & 30,4837 & 1,7784 & 31,15 & 31,15 & 1,7821 \\
\hline
\end{tabular}

Berdasarkan Tabel 11., maka grafik biaya bahan bakar harian PLTU Barru pada 05 Mei 2016 dengan berbagai metode dapat dilihat pada Gambar 3.

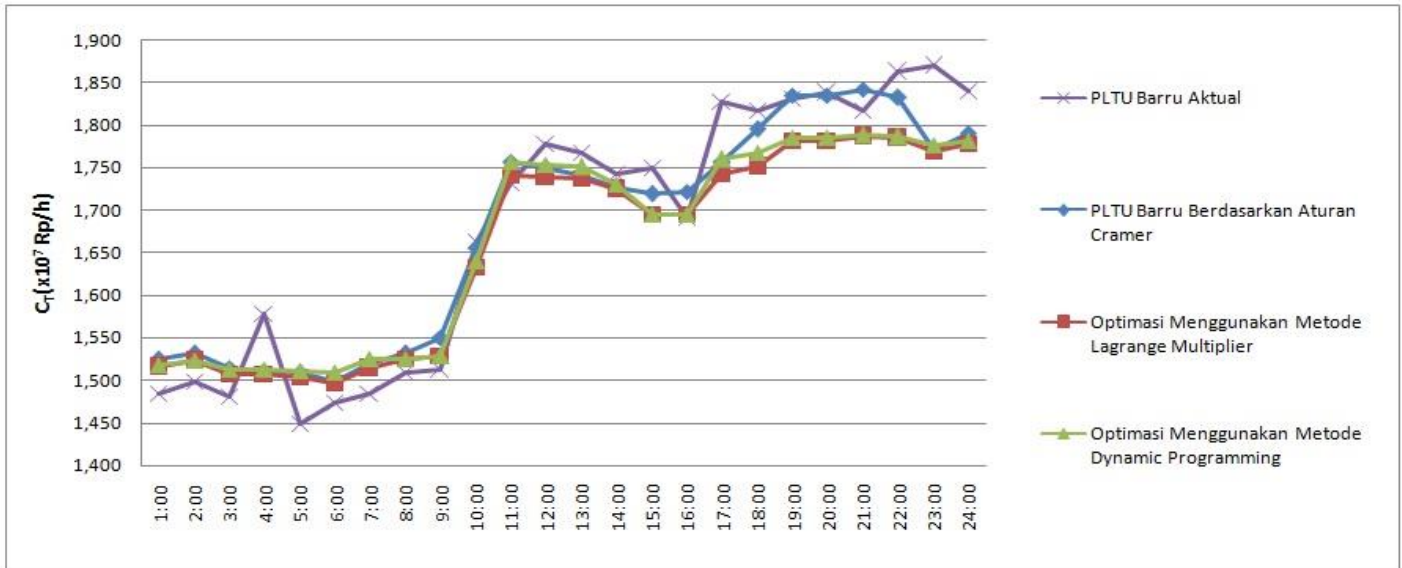

Gambar 3. Perbandingan Biaya Bahan Bakar Harian PLTU Barru pada 05 Mei 2016 dengan Berbagai Metode 
78 Remigius Tandioga, Musrady Mulyadi, Azwar, Widya Wirawati Rauf. Optimasi Operasi Unit-Unit Pembangkit Pada PLTU Barru

Pada Gambar 3, dapat dilihat beban tertinggi tanggal 05 Mei 2016 terjadi pada jam 21:00 dimana pada saat itu total daya sebesar 62,70 MW dengan biaya bahan bakar PLTU Barru secara aktual sebesar Rp $1,817 \times 10^{7} / \mathrm{h}$ dan diperoleh biaya bahan bakar PLTU Barru berdasarkan aturan Cramer sebesar Rp 1,842 × $10^{7} / \mathrm{h}$, optimasi menggunakan metode Lagrange multiplier sebesar $\mathrm{Rp}$ $1,7859 \times 10^{7} / \mathrm{h}$, sedangkan dengan metode optimasi menggunakan dynamic programming sebesar $\mathrm{Rp}$ $1,7877 \times 10^{7} / \mathrm{h}$. Sehingga model operasi yang optimal pada jam 21:00 ialah menggunakan metode Lagrange multiplier dengan $\mathrm{P}_{1}$ sebesar 31,8165 MW, sebesar $\mathrm{P}_{2}$ sebesar 30,7833 MW.

\section{KESIMPULAN} berikut:

Berdasarkan hasil dan pembahasan yang telah dilakukan, maka dapat disimpulkan sebagai

1. Dari hasil pengolahan data diketahui optimasi operasi unit-unit pembangkit pada PLTU Barru dengan menggunakan metode Lagrange multiplier lebih optimal dibandingkan dengan metode dynamic programming meskipun memiliki nilai yang hampir sama.

2. Dari hasil penelitian, pada umumnya hasil perhitungan lebih optimal dibandingkan kondisi nyata PLTU Barru. Khususnya pada bulan Mei 2016, hasil perhitungan yang optimal sepanjang hari (selama 24 jam) yaitu tanggal 7 dengan daya total 56,7 MW (56,7\%), tanggal 20 dengan daya total $70,1 \mathrm{MW}(70,1 \%)$, tanggal 21 dengan daya total 72,5 MW (72,5\%), tanggal 26 dengan daya total $77,8 \mathrm{MW}(77,8 \%)$, tanggal 27 dengan daya total 82,4 MW (82,4\%), tanggal 28 dengan daya total 80,73 MW (80,73\%), tanggal 29 dengan daya total 83,45 MW (83,45\%), tanggal 30 dengan daya total 75,7 MW (75,7\%), dan tanggal 31 dengan daya total 84,05 MW (84,05\%). Adapun kondisi nyata PLTU Barru lebih optimal dibandingkan hasil perhitungan dengan daya total rata-rata 50,36 MW (50,36\%) yaitu pada tanggal 4 jam 17:00 - 24:00, tanggal 5 jam 01:00 - 16:00, tanggal 6 jam 01:00 - 17:00, tanggal 8 jam 17:00 - 24:00, tanggal 10 jam 01:00 - 08:00, tanggal 11 jam 01:00 12:00, tanggal 18 jam 01:00 - 12:00, tanggal 19 jam 01:00 - 02:00, tanggal 22 jam 06:00, dan tanggal 25 jam 21:00 - 22:00, diluar dari waktu tersebut hasil perhitungan menunjukkan nilai optimal.

3. Dari hasil perhitungan biaya tarif dasar berdasarkan metode Lagrange multiplier dan dynamic programming menyatakan bahwa unit 1 memiliki biaya tarif dasar lebih murah dibandingkan unit 2. Hal ini dibuktikan dengan hasil perhitungan yang dilakukan pada tanggal 05 Mei 2016 yaitu biaya tarif dasar pada unit 1 sebesar Rp 282,926 / kWh dan pada unit 2 sebesar Rp 326,899 / kWh

\section{DAFTAR PUSTAKA}

[1] Herdianto. 2015. Laporan PKL Kinerja Boiler PLTU Barru. Politeknik Negeri Ujung Pandang. Makassar.

[2] Kholisoh, Dyar. 2008. Optimasi Numerik dan Analisis Numerik. Yogyakarta: Universitas Islam Indonesia

[3] Angdrie, S. V. (2012). Optimalisasi Biaya Bahan Bakar Untuk Penjadwalan Unit-Unit Pada Pembangkit Thermal Sistem Minahasa Dengan Metode Iterasi Lamda. Jurnal Teknik Elektro dan Komputer, 1(2).

[4] Syam, S. (2020). Optimasi Pembangkit Listrik Hidro-Termal Dengan Menggunakan Metode Gradien Orde Dua. Deepublish.

[5] Siswanto, M., Hermawan, H., \& Syakur, A. (2011). Mengoptimalkan Pembagian Beban Pada Unit Pembangkit Pltgu Tambak Lorok Dengan Metode Lagrange Multiplier (Doctoral dissertation, Jurusan Teknik Elektro Fakultas Teknik Undip).

[6] Kanata, S. (2017). Pembangkitan Ekonomis pada Unit Pembangkit Listrik Tenaga Diesel Telaga Gorontalo Menggunakan Algoritma Genetika. Jurnal Rekayasa Elektrika, 13(3), 119-124. 
[7] Hadinanto, H., Asmar, A., \& Gusa, R. F. (2018, October). Optimasi Pembangkitan Ekonomis Unit-Unit Pembangkit Listrik Tenaga Diesel Menggunakan Metode Particle Swarm Optimization (PSO) Studi Kasus di PLTD Merawang. In Proceedings of National Colloquium Research and Community Service (Vol. 2).

[8] Zhu, J. (2015). Optimization of power system operation. John Wiley \& Sons.

[9] Bertsekas, D. P. (2014). Constrained optimization and Lagrange multiplier methods. Academic press.

[10] Marsudi, D. (2006). Operasi sistem tenaga listrik. Yogyakarta: Graha Ilmu.

[11] Grainger, J. J. (1999). Power system analysis. McGraw-Hill.

[12] Idris, A. R. (2013). Studi Optimasi Operasi Pembangkit Tenaga Listrik Dengan Metode Pemrograman Dinamik. PROGRES, 5(2), 55-66.

[13] Indriani, A. (2006). Optimasi Penjadwalan Unit Pembangkit Thermal dengan Dinamics Programming. In Seminar Nasional Aplikasi Teknologi Informasi (SNATI). 